Document downloaded from:

http://hdl.handle.net/10251/97908

This paper must be cited as:

Peña-Rojas, LE.; Barrios Peña, MI.; Francés, F. (2016). Flood quantiles scaling with upper soil hydraulic properties for different

land uses at catchment scale. Journal of Hydrology. 541:1258-1272.

doi:10.1016/j.jhydrol.2016.08.031

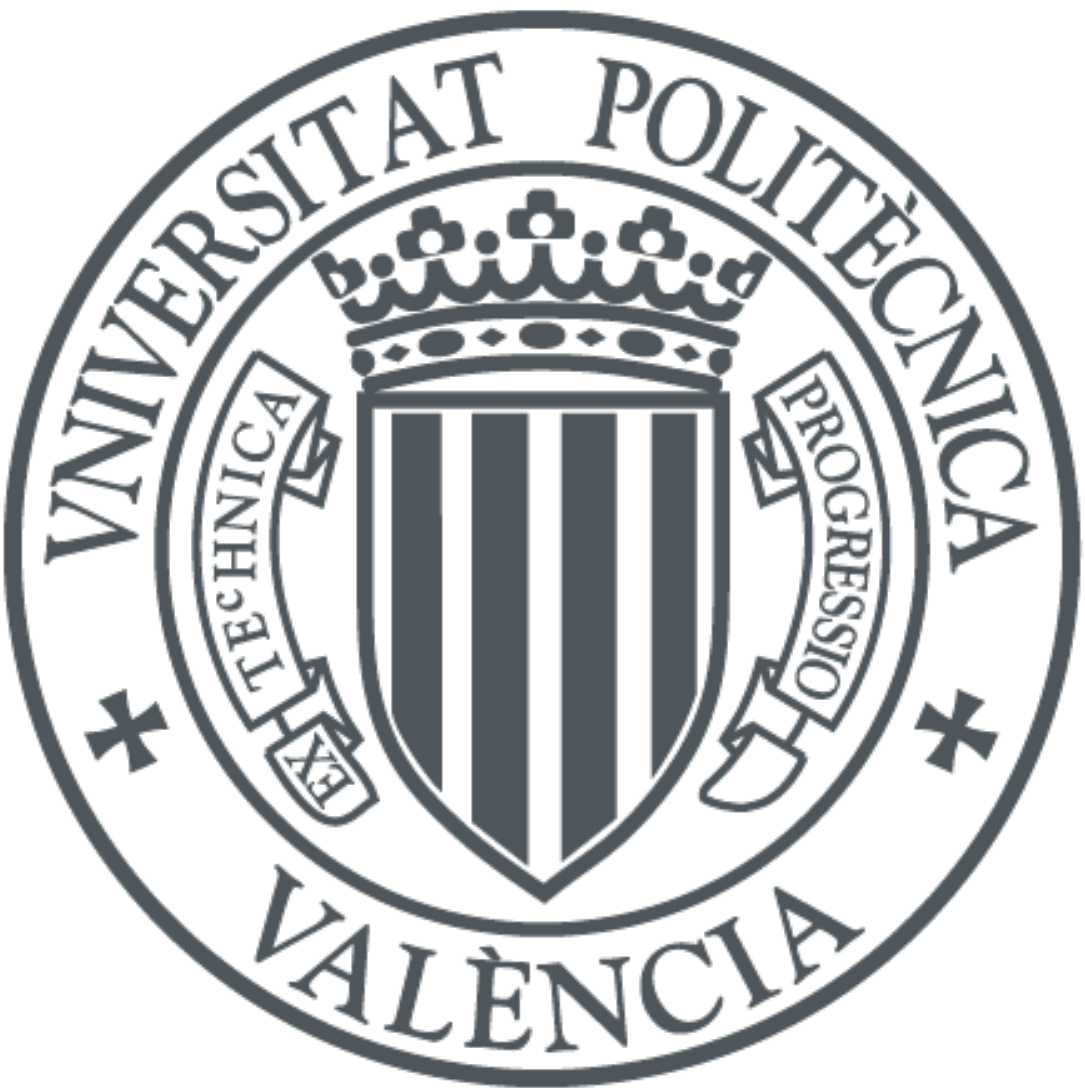

The final publication is available at

http://dx.doi.org/10.1016/j.jhydrol.2016.08.031

Copyright Elsevier

Additional Information 


\section{Flood quantiles scaling with upper soil hydraulic properties for different land uses at catchment scale}

a Civil Engineering Program, Engineering Faculty, Universidad de Ibagué, Carrera 22 calle 67 B/Ambalá, 730001, Ibagué, Colombia

${ }^{b}$ Faculty of Forest Engineering, Universidad del Tolima, B/Santa Helena, 730006299, Ibagué, Colombia

c Research Institute on Water and Environmental Engineering, Universitat Politècnica de València, Camino de Vera s/n, 46022 Valencia, Spain

\section{Abstract}

Changes in land use within a catchment are among the causes of non-stationarity in the flood regime, as they modify the upper soil physical structure and its runoff production capacity. This paper analyzes the relation between the variation of the upper soil hydraulic properties due to changes in land use and its effect on the magnitude of peak flows: 1) incorporating fractal scaling properties to relate the effect of the static storage capacity (the sum of capillary water storage capacity in the root zone, canopy interception and surface puddles) and the upper soil vertical saturated hydraulic conductivity on the flood regime; 2) describing the effect of the spatial organization of the upper soil hydraulic properties at catchment scale; 3) examining the scale properties in the parameters of the Generalized Extreme Value (GEV) probability distribution function, in relation to the upper soil hydraulic properties. This study considered the historical changes of land use in the Combeima River catchment in South America, between 1991 and 2007, using distributed hydrological modeling of daily discharges to describe the hydrological response. Through simulation of land cover scenarios, it was demonstrated that it is possible to quantify the magnitude of peak flows in scenarios of land cover changes through its Wide-Sense Simple Scaling with the upper soil hydraulic properties.

Keywords: Land use change, scaling, hydraulic properties of soil, flood regime, GEV distribution 
Historically, changes in land use have taken place due to human activities as agriculture, forestry, settlements, and roadway construction (Bronstert, 2003). These activities interact to create combined effects on the flow regimes, altering significantly flood frequency distribution (Whitfield, 2012). Hence, the evaluation of changes in land use and their effect on the hydrological response at catchment scale is one of the fundamental challenges in Hydrology (Elfert \& Bormann, 2010). Studies on this topic have demonstrated changes in the hydrologic regime because of land cover changes, although this effect is difficult to quantify (Alaoui et al., 2014), especially in the long term and at catchment scale for flood regime, because their intensity is a function of the size of the change (in relation to total area), slope, type of soil and characteristics of the precipitations (Quilbé et al., 2008).

Transitions from grasslands to forests and crops could represent a potential to reduce flood risk, given their contribution to diminish maximum flows, especially at small catchments as reported by Marshall et al, (2014). And vice versa, the transition from forest to grassland increases the rate and total runoff during storms (Mao \& Cherkauer, 2009).

Likewise, land use changes and climatic variability induce short-term changes in peak flows (Jung et al., 2011). Additionally, it has been accepted that increased runoff is associated to increased imperviousness in the catchments, which contributes to increased flood peaks, due to the decrease of surface infiltration and deep percolation (Wijesekara et al., 2012). Mao and Cherkauer (2009) found increased runoff and reduction in evapotranspiration for the conversion of forests to grasslands, and a rise in evapotranspiration and a decline in runoff rates for the transition from grassland to crops. Similar behavior has been observed in pasture areas that were later changed to shrubs, which modified the characteristics of hillside soils, increasing runoff and reducing infiltration (Abrahams et al., 1995). Diminished runoff and attenuated response to flood events triggered by rainfall have been observed in reforestation scenarios 
54 (Eckhardt et al., 2003). Such effects of land use changes on runoff are mainly attribuable to 55 gradual alterations of soil hydraulic properties as infiltration capacity and saturated hydraulic conductivity (Gupta et al., 2006; Zhou et al., 2008).

57 Changes in land use modify the texture and chemical characteristics of soil (Koinig et al., 2003), and-in turn-its saturated hydraulic conductivity. Saturated hydraulic conductivity is a function of the size and continuity of the structure of pores in the soil and it changes gradually over time (Kumar et al., 2008). Changes in saturated hydraulic conductivity could also be induced by manmade actions, like tillage and irrigation of crops (Bhattacharyya et al., 2006). This is related to the type of vegetation and depth of its roots, which influence the soil hydraulic behavior. Hence, changes in land use induce changes in the soil infiltration capacity, which determines the hydrological response of the catchments (Zhang et al., 2001) and alters the flow variability pattern (Hopmans et al., 2002).

Based on field measurements, Kumar et al. (2008) found hydraulic conductivity increased in transition from grassland to agroforestry buffers. It has been as well shown that hydraulic conductivity was reestablished upon performing measurements on lands dedicated to grasslands, which then evolved to crops, indicating that the variation is due to the modification of pore distribution in the soil structure (Kodesová et al., 2011). In lands with transition from grasslands to forests, diminished soil erosion was observed, along with increased water availability in plants and reduced flood risk (Agnese et al., 2011). It is widely believed that the mean volume of pores is higher for forest soils and lower for crops and grasslands, thereby influencing the soil hydraulic conductivity values (Chen et al., 2009).

It has been accepted that water storage in the soil is controlled by the geometry of pore spaces and the soil structure (Schwärzel et al., 2011), which determine the soil humidity retention capacity and infiltration. These in turn are influenced by soil composition, type of vegetation, 
conductivity have been found in the root zone (Niemeyer et al., 2014), whereas the opposite occurs for soils with grassland (Zimmermann et al, 2006). Thus, water storage processes in the root zone, surface flow, infiltration, and water retention in the landscape are mainly relevant in runoff generation during storms (Salazar et al., 2012) and are essential in the distribution of flood frequency and magnitude (De Michele \& Salvadori, 2002).

Evaluation of the hydrological response of catchments under scenarios of land use changes has been based on the analysis of exceedance probabilities in flow series (Burn \& Whitfield, 2015; McCormick et al., 2009), the identification of runoff characteristics through hydraulic simulation, analysis of satellite images, and use of geographic information systems (Sajikumar \& Remya, 2014). Numerical simulation and generation of synthetic rainfall have also been used to determine the effect of land use changes (Kuraś et al., 2012). Hydrological modeling has permitted considering evapotranspiration variation, surface flow, and infiltration capacity, which is determined by root depth (Öztürk et al., 2013) and modifies the soil hydraulic properties according to land use changes (Salemi et al., 2013). Several hydrological models have been used to compare these effects (see for example Cornelissen et al., 2013).

Understanding the impact of land use change on the hydrology at catchment scale may facilitate to design strategies for sustainable development of water resources (Ghaffari et al., 2010). Our assumption is that land use changes modify soil hydraulic characteristics. The main aim of this paper is then to describe and analyze the effect of changes of upper soil hydraulic properties on the flood regime based on hydrological modeling, and exploring the potential scaling of maximum annual flows with these soil properties. 
103 The Combeima River catchment (Fig. 1) is located in the mountainous zone of the Colombian

104 Andes. The closing point was defined at the 2121180-Montezuma hydrometric station, which is 105 located at an elevation of $1450 \mathrm{~m}$ and covers an area of $217.29 \mathrm{~km}^{2}$. This study used daily 106 information reported by this hydrometric station and nine weather stations (Fig. 2) during the 107 period between 1971 and 2012 (García et al., 2016). Precipitation in the lower Combeima River catchment is higher than in its upper basin (Fig. 2), it presents a bimodal annual distribution and it has a mean of $1673 \mathrm{~mm} / \mathrm{year}$. The annual mean flow is $5.6 \mathrm{~m}^{3} \mathrm{~s}^{-1}$. Rainfall datasets are scarce in the catchment for the altitude range of 2200 to 5150 m.a.s.l. For improving the spatial representation of rainfall, three virtual rainfall stations

112 were generated using a Pearson's correlation weighting approach with two rainfall stations 113 located near to Combeima catchment at 3280 and 4150 m.a.s.l. However this catchment was 114 selected because of information availability on land use historical evolution, so its effect on the 115 hydrological response of mountainous catchments in tropical latitudes can be analyzed. 

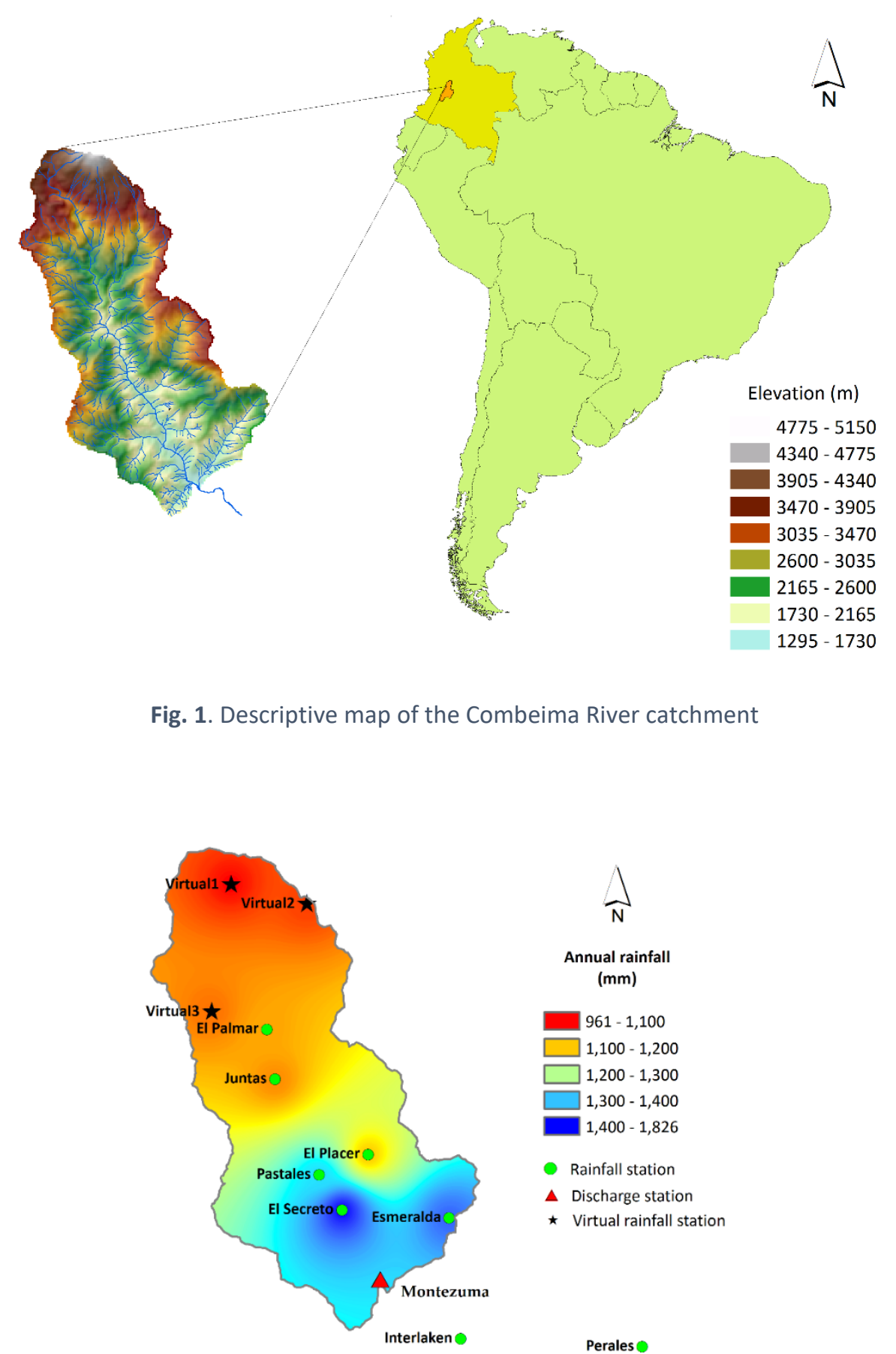

Fig. 2. Combeima River catchment spatial variation of annual rainfall for the period 1971-2012.

122 The main types of land cover in the Combeima River catchment are forest, grasslands, crops and

123 impervious areas. The forests are composed mainly by tropical evergreen forest (ARALIACEAE,

124 BORAGINACEAE, COMPOSITAE, EUPHORBIACEAE, MELASTOMATACEAE, MELIACEAE, and

125 SOLANACEAE), the grasslands are dedicated to livestock and the main crops in the region are 
coffee, lulo fruit, blackberry and corn (Coffea sp, Solanum quitoense, Morus sp and Zea mays,

127 respectively). The impervious areas represent a relative low percentage of the catchment and are related to small villages, rock outcrops and glaciers. However, the spatial distribution of land cover has changed in time. In 1991, $48.9 \%$ of the Combeima River catchment was comprised of forests, $20.3 \%$ crops, $28.3 \%$ grasslands and $2.5 \%$ impervious surfaces. Later, in 2000 , land use changes resulted in decreased forest (45.9\%) and crop areas (13.8\%), and increased grassland areas (38.9\%). This trend was reversed in 2002 , when crop (17.8\%) and forest areas (46.1\%) increased while grassland areas decreased (33.1\%). Finally, in 2007, trends in land use changes forest (49.1\%) and crop areas (21.5\%) increased and grassland areas (27\%) decreased, as a result of implementing environmental regulations in the region.

To describe land use changes, maps of soil types and land use were integrated resulting data of sand, silt, clay and organic matter contents, as well as root depth for each land use, which were used to generate maps of the hydraulic properties of soil, employing the pedotransfer function presented by Saxton and Rawls (2006). The variations of the interception capacity and evapotranspiration were incorporated depending on the types of land use considered in this study (Table 1).

According to the study conducted by the Colombian Geographic Institute (IGAC), soils in the upper basin are deep clay-loams of volcanic origin, well drained, with medium to coarse textures, slopes greater than $50 \%$, and high content of organic matter (MDA, MGC and MKG units). Bedrock outcrops (MAA units) are observed in the highest elevation of the catchment, corresponding to the volcanic cone. Soils in the middle basin are clay-sands from the MGB unit, with low depth and high content of organic matter. Soils in the MKB unit are clay-loams and clay-sands with slopes greater than $50 \%$, rich in organic matter and well drained. The soils in MQO unit coincide with the main stem of the basin, have slopes between $3 \%$ and $7 \%$, are prone to flooding and are basically alluvial sediment soils, with medium to coarse textures and low 
content of organic matter. The MQC units are located in slope areas between $50 \%$ and $70 \%$, are deep, with medium to moderately fine textures and are rich in organic matter. Soils in the MQD unit in the low basin are clay-loams and clay-gravels with slopes between $20 \%$ and $50 \%$, low depths and highly drained. Finally, NP unit corresponds to the glacial zone (Fig.3).

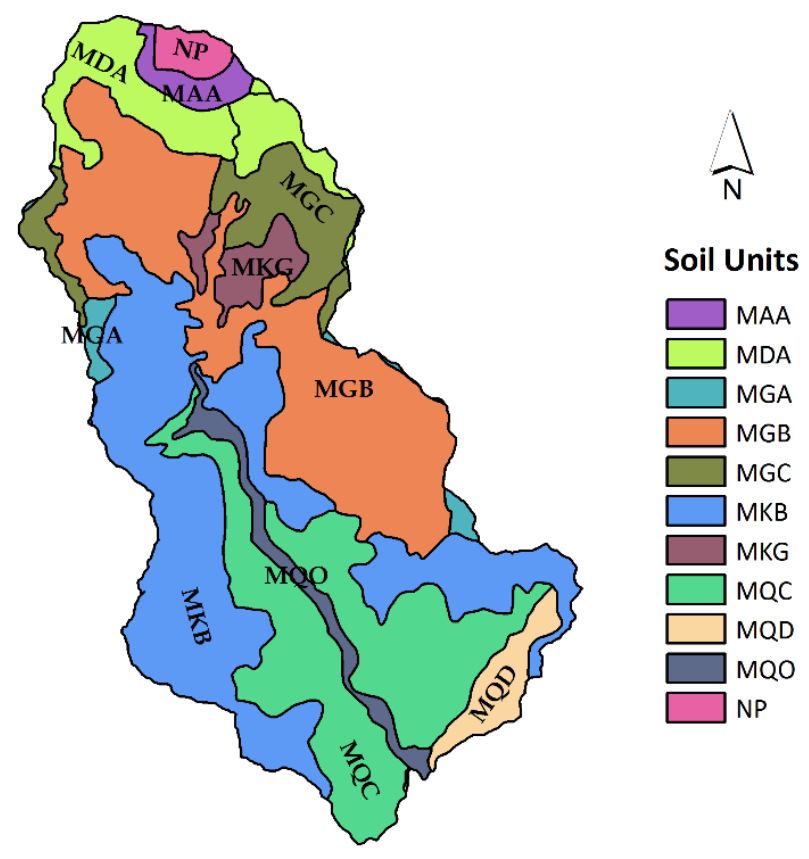

Fig. 3. Soil units in the Combeima River catchment (legend explanation in the text).

\subsection{Hydrologic modeling}

The hydrological model used in this paper was TETIS. It is a conceptual distributed hydrological model, with physically sound parameters, able to perform continuous and event based simulations of the water cycle and which has been applied successfully in catchment areas ranging from less than $1 \mathrm{Km}^{2}$ to $60,000 \mathrm{Km}^{2}$, with grid cell resolutions from $30 \times 30 \mathrm{~m}$ to $500 \times 500$ $\mathrm{m}$ and in a wide range of climates. Some examples of its successful application can be found in Francés et al. (2007), Vélez et al., (2009), Andrés-Doménech et al. (2010), Salazar et al. (2012), Bussi et al. (2014) and Ruiz-Villanueva et al. (2015). 
166 According to Francés et al. (2007), in TETIS each cell of the spatial grid simulates the water cycle

167 through five linked compartments. Each compartment represents different hydrological processes described by linear reservoirs (Fig. 4). TETIS includes modules for snowmelt, canopy interception, soil capillary storage and interflow, evapotranspiration, aquifer storage and base flow (connected aquifer flow). Each cell receives the flow from the upstream cell above and drains to the downstream cell, following the digital elevation model flow directions. Compartment or tank T0 represents the snowpack and T1 is the static storage, which represents upper soil humidity below field capacity, canopy interception and storage in surface depressions

174 (puddles), the tank T2 represents water over the surface that can flow as overland runoff or 175 infiltrate, $\mathrm{T} 3$ is the storage in the upper part of the soil above field capacity and T4 is the water 176 storage in the aquifer. For the configuration used in this paper (the simplest), the only output 177 from T1 corresponds to evapotranspiration and overland flow, interflow and base flow drain 178 directly in the river channel network, represented by the compartment T5. Finally TETIS 179 describes the flow routing in the stream network using the Geomorphologic Kinematic Wave methodology (Francés et al., 2007). 


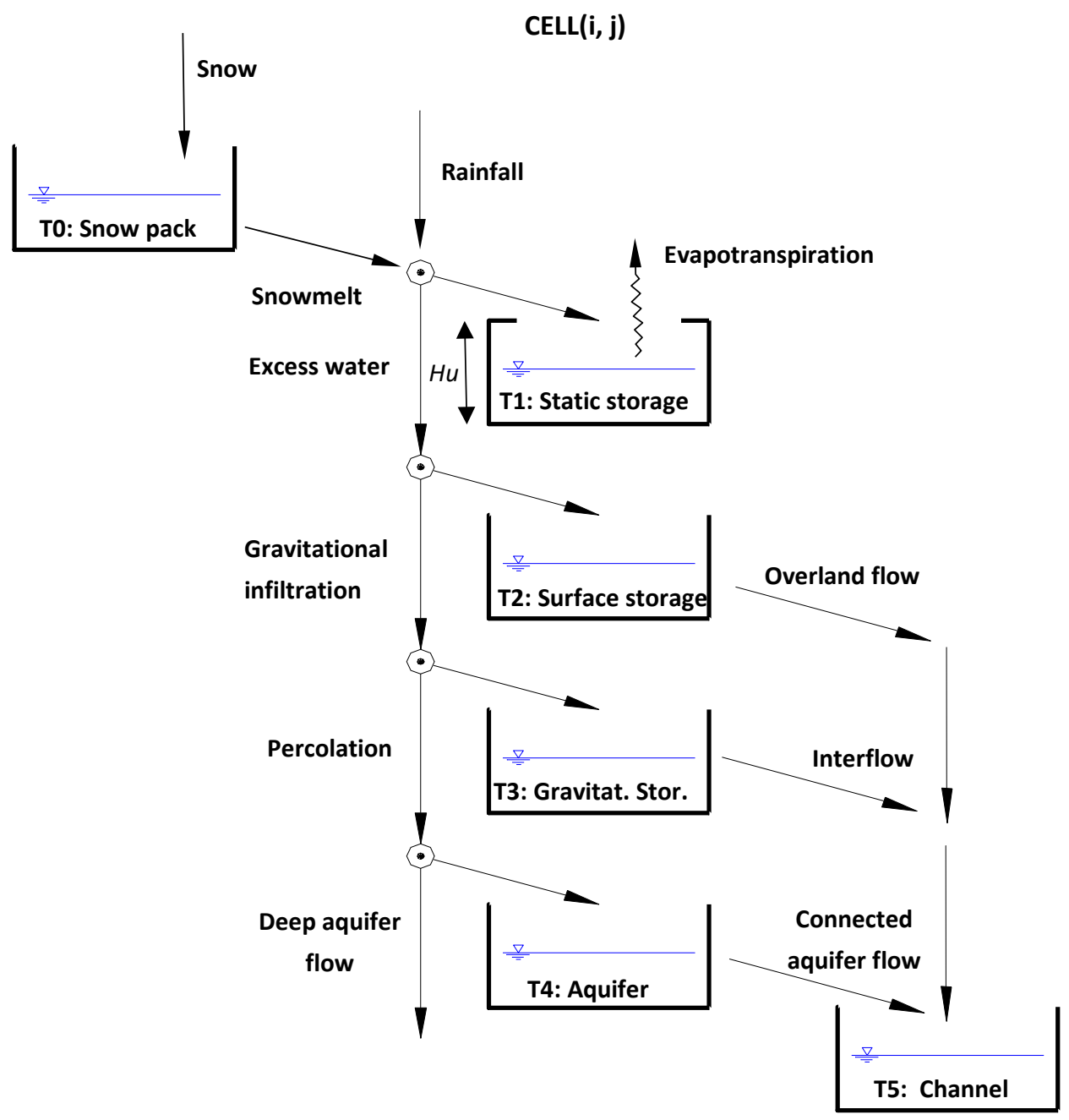

Fig. 4. Conceptual scheme of TETIS hydrological distributed model used in this paper (simplest configuration)

186 production: $\mathrm{Hu}$ (static storage capacity) and Ks (upper soil vertical saturated hydraulic conductivity). Parameter $\mathrm{Hu}$ is the storage capacity of the static tank $\mathrm{T} 1$ and can be estimated as:

189

$H_{u}=\sum_{i} h_{i} A W_{i}+I_{\text {max }}+A_{s}$

where $h_{i}(\mathrm{~mm})$ and $A W_{i}$ are the depth and available water (the difference between the field capacity and wilting point) for each soil horizon respectively, $A_{s}$ is the surface maximum depression storage $(\mathrm{mm})$, which is essentially a function of land cover and topographic slope, 
and Imax is the canopy maximum interception ( $\mathrm{mm}$ ). The summation in Eq. (1) is up to the minimum value between soil depth and effective root depth is reached.

In the simplest TETIS configuration, it is assumed that the infiltration capacity is infinite below field capacity, i.e., rainfall plus snowmelt go directly to T1 up to this tank is filled. Then, after T1 ponding, excess water con flow as overland flow through $\mathrm{T} 2$ or infiltrate to $\mathrm{T} 3$, with an infiltration capacity approximately equal to the vertical saturated hydraulic conductivity of the upper soil $(K s)$. This infiltration above field capacity can be called "gravitational infiltration".

\subsubsection{Parameter estimation}

The TETIS model parameters (including $H u$ and $K s$ ) were estimated as a result of the integration of various input maps: the digital elevation model, soil types, land uses, geology and geological faults. The digital elevation model (DEM) of the catchment, with a grid cell size of $90 \times 90 \mathrm{~m}$, was obtained from NASA's Shuttle Radar Topography Mission. The IGAC-generated maps of soil units and geology and geological faults at scales of 1:500,000 and 1:25,000, respectively, were also used. Maps of slopes, flow direction and overland hillside flow velocity, drainage network, and cumulative cells were generated from the DEM. Percolation rate and aquifer permeability maps were estimated from the geology and geological fault maps. Soil and soil substrate parameters were determined by using sites sampled in each map unit (Fig. 3), corresponding to an edaphic type, as reported by IGAC.

Land cover and land use changes were obtained based on information contained in maps for 1991, 2000, 2002, and 2007 of Combeima River catchment. These maps were generated by IGAC at a scale of 1:25,000. Four general types of land cover and effective root depth were defined as follows: forests $(2.0 \mathrm{~m})$, crops $(0.6 \mathrm{~m})$, grasslands $(0.4 \mathrm{~m})$ and impervious surfaces $(0.0 \mathrm{~m})$. Values of root depth were based in Rivera (2008) and can be seen in Table 1. 
217 Seasonal variation of evapotranspiration was introduced by adopting mean values of the

218 coefficient of consumptive use $(\lambda \mathrm{m})$ for each type of land cover in the catchment, based on

219 values reported by Allen et al. (1998) and our experience (Table 1).

220

221 The overlaying of soil type and land use maps resulted in polygons where the hydraulic

222 properties of upper soil can be estimated by using pedotransfer functions (Saxton \& Rawls,

223 2006). Additionally, Eq. (1) is required for the final computation of $H u$. The estimated parameters

224 are actually modal values (i.e., representative of the estimated characteristic rather than an

225 exact mean) and are presented in Fig. 5 for all combinations of land uses and soil types. These

226 values are assigned to each cell and, therefore, allowing the introduction of the spatial variability

227 of land use changes to each simulated scenario. The aggregations in box-plots of $H u$ and $K s$

228 values for each land cover are displayed in Fig. $5 c$ and $5 d$ respectively. For this case study, there

229 is a clear $\mathrm{Hu}$ and $\mathrm{Ks}$ parameters change between the main land covers, resulting the forest land

230 cover with higher values than grassland areas. 

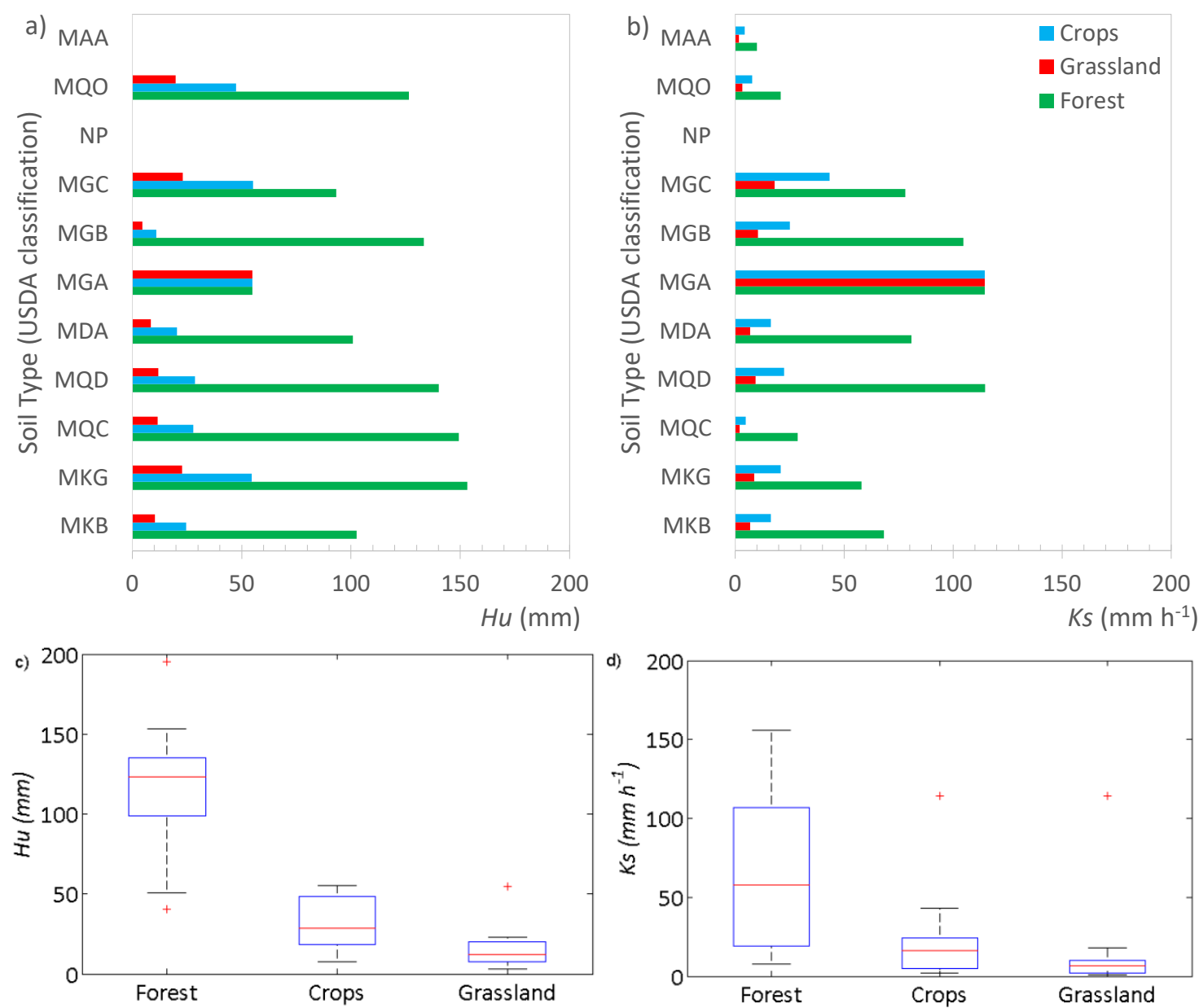

Fig. 5. Estimated upper soil hydraulic parameters by soil type and land use: a) for static storage capacity $\mathrm{Hu}$; b) for vertical saturated hydraulic conductivity $\mathrm{Ks}$; $\mathrm{c}$ and d) box-plots (aggregated by land covers) for $H u$ and $K s$ respectively.

Table 1. Consumptive use $\lambda_{m}$ and interception capacity $I_{\max }$ used in the implementation of the hydrological model

\begin{tabular}{lllllllllllllll}
\hline Land cover & $\lambda_{\text {jan }}$ & $\lambda_{\text {feb }}$ & $\lambda_{\text {mar }}$ & $\lambda_{\text {apr }}$ & $\lambda_{\text {may }}$ & $\lambda_{\text {jun }}$ & $\lambda_{\text {jul }}$ & $\lambda_{\text {ago }}$ & $\lambda_{\text {sep }}$ & $\lambda_{\text {oct }}$ & $\lambda_{\text {nov }}$ & $\lambda_{\text {dec }}$ & $\begin{array}{c}I_{\text {max }} \\
(\mathbf{m m})\end{array}$ \\
\hline Forest & 0.60 & 0.75 & 0.85 & 1.00 & 1.00 & 1.00 & 1.00 & 1.00 & 1.00 & 0.85 & 0.75 & 0.60 & 9.00 & 2.00 \\
$\begin{array}{c}\text { Effective } \\
\text { root } \\
\text { depth } \\
\text { (m) }\end{array}$ \\
$\begin{array}{l}\text { Graps } \\
\begin{array}{l}\text { Impervious } \\
\text { surfaces }\end{array}\end{array}$ & 0.30 & 0.35 & 0.50 & 0.60 & 0.77 & 0.90 & 0.98 & 1.00 & 1.00 & 0.98 & 0.90 & 0.78 & 2.00 & 0.60 \\
\hline
\end{tabular}

\subsubsection{Model implementation}

238 Effective parameters in TETIS hydrological model have a split-parameter structure (Francés et

239 al., 2007). In this approach, parameter maps were estimated from cartographic information

240 (soils, land cover, topography and geology, among others) and model effective parameter values

241 were modified by a single correction factor for each parameter map. The correction factors are 
the variables which actually are calibrated in TETIS. According to the split-parameter structure, parameter maps influenced by land cover can be updated to show land cover changes, but the calibrated correction factor for each parameter map is preserved. In other words, the calibrated correction factors can extend the calibration to periods with different land uses and climate.

To calibrate the correction factors, TETIS program can performs its automatic optimization through the SCE-UA method (Duan et al., 1994), in this paper was used the well-known NashSutcliffe efficiency index (NSE) as the objective function. In this case study, the calibration was carried out for the 2007-2008 period, which is closest to the year with the most-recent map of land uses in the Combeima River catchment and complete hydro-climatic information were available, i.e., year 2007. Validation was carried out for the periods $1998-2000$ and 1984, by keeping constant the values of correction factors obtained during model calibration.

\subsubsection{Land use simulation scenarios}

The analysis of the effect of land use changes on the flood regime of the Combeima River catchment was based on the modeling of hydrological processes through the variation of model parameters associated to evapotranspiration and runoff production.

In addition to the reported historical land use changes, watershed planning was simulated by considering the plan defined by the local environmental authority; this scenario was denominated Esc1. Also, three homogeneous scenarios were included with catchment coverage totally of forest, crops and grassland, in order to describe the extreme effect of each land cover on the flood regime. Table 2 summarizes the land use scenarios used in this paper. All land use scenarios were simulated applying the historical meteorological information for the period from 1971 to 2012 , without correcting the possible trends in temperature and precipitation. 
Table 2. Land use simulation scenarios.

\begin{tabular}{lc}
\hline Description & Scenario code \\
\hline 1991 land cover map & 1991 \\
2000 land cover map & 2000 \\
2002 land cover map & 2002 \\
2007 land cover map & 2007 \\
Land Use Plan & Esc1 \\
Forest land cover & Forest \\
Crops land cover & Crops \\
Grassland land cover & Grassland \\
\hline
\end{tabular}

267

\subsection{Statistical scaling of floods}

269 Simple Scaling and Multi-scaling have been used during the last 20 years to study the frequency

270 relations of spatial or regional floods and the physical mechanisms that generate them

271 (Robinson \& Sivanapalan, 1997). The application of scaling properties has been useful in

272 predicting flows in catchments where scarce or no information is available (GREHYS, 1996;

273 Srinivas et al., 2008). This is mainly because the scale exponents of flood quantiles introduce

274 invariance with respect to the spatial flood variability. The key point in scaling analysis is to find

275 the appropriate scale definition.

276 Gupta and Waymire (1990) defined Strict-Sense Simple Scaling to describe the equality of the

277 probability distribution of precipitations (in general, any random variable $Y$ ) in two different

278 scales as:

$279 \quad Y_{\lambda} \stackrel{\text { def }}{=} \lambda^{\alpha} Y_{S}$

280 where the $\stackrel{\text { def }}{=}$ symbol indicates equality in the distribution of probabilities, $\lambda$ is the scale factor

$281(\lambda>0)$ and $\alpha$ is the scale exponent. If $Y_{\lambda}$ have finite ordinary moments $E\left[Y_{\lambda t}^{r}\right]$ of $r$ order and the

282 random variables $Y_{\lambda}^{r}$ and $\left(\lambda^{\alpha} Y_{S}\right)^{r}$ follow the same probability distribution, then the ordinary moments can be scaled in this way:

$m_{r}=E\left[Y_{\lambda}^{r}\right]=\lambda^{\alpha r} E\left[Y_{1}^{r}\right]$ 
where it must be underlined the scale exponent is a linear function of $r$. The property defined by Eq. (3) is known as Wide-Sense Simple Scaling (WSSS). According to Vaskôva (2001), WSSS may be reflected in two forms: i) identifying the linearity of the logarithm of moments $m$ of order $r$ expressed as $\operatorname{logm}_{r}(\lambda)$ versus $\log \lambda$ for each $r$; and ii) through the linearity of the scale exponent with $r$.

The GEV was selected as the probability function for flood quantile estimation in the Combeima River catchment, because it has been widely used for the analysis of extreme values, it is a generalization of the Extreme Value family (i.e., Gumbel, Weibull and LogGumbel distributions) and, more important in this paper, it has been proven to be adequate for modeling flood scaling (Villarini, 2010). The expression of its cumulative distribution function is:

$F(Y)=\exp \left\{-\left[1-\frac{\kappa(Y-\beta)}{\alpha}\right]^{\frac{1}{\kappa}}\right\}$

where $\alpha, \beta$ and $\kappa$ are the scale, location and shape parameter respectively. The parameters of the GEV distribution were estimated through the Maximum Likelihood (ML) method, because of its advantagesin the type of problem to be solved (see for example Morrison \& Smith, 2002 and Botero \& Francés, 2010). Details for the parameter estimation using ML method are given in Appendix A.

The main hypothesis in this paper is that moments and GEV parameters can be expressed as a function of the spatial average of $H u$ and $K s$. I.e., floods follow WSSS and the GEV parameters can be given by:

$\alpha_{\lambda}=\alpha_{0} \lambda^{-a}$

$\beta_{\lambda}=\beta_{0} \lambda^{-b}$

$\kappa_{\lambda}=\kappa_{0} \lambda^{-c}$

where scale $\lambda$ can be $H u$ or $K s$. 


\subsection{Modeling of land use changes}

312 Land uses in the Combeima River catchment were reclassified into four groups: forests, crops, grassland, and impervious surfaces; $H u$ and $K s$ values were obtained from the pedotransfer functions, as indicated in Section 2.2.1. Therefore, changes in land use changed the values of the upper soil hydraulic parameters. The resulting maps for historical land uses and planned

316 scenarios are shown in Fig. 7. From this figure, it is clear the significant changes in the spatial

317 distribution of upper soil hydraulic parameters between different land use scenarios. 

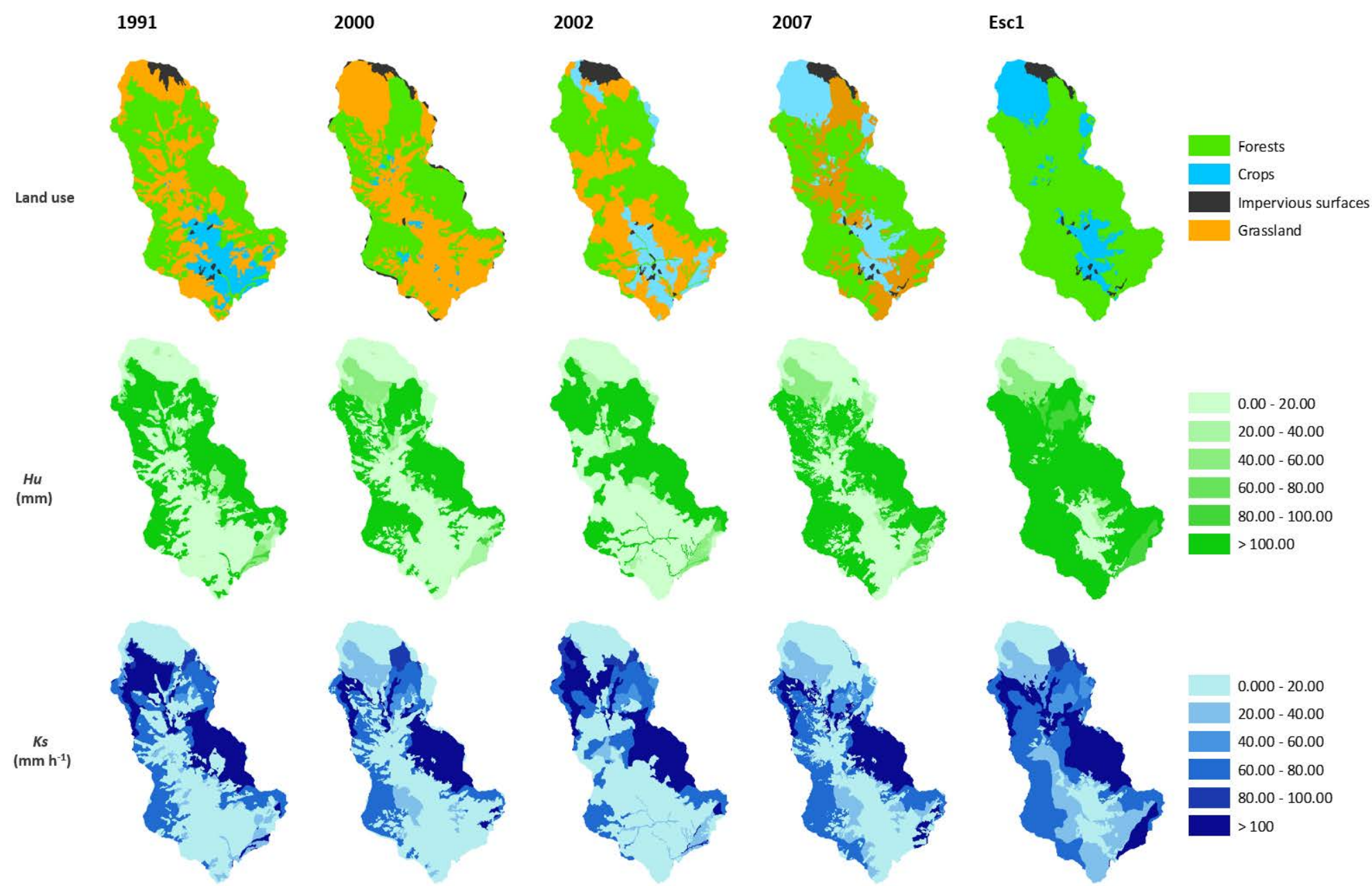

Fig. 6. Historical (period 1991-2007) and planned (Esc1) land uses and values for Hu and Ks for the Combeima River catchment 
321 For the model performance evaluation, we have used the well-known in hydrological modelling

322 Nash-Sutcliffe efficiency index (NSE) and the Root Mean Square Error (RMSE). In calibration, a NSE

323 value of 0.5167 and RMSE of 1.209 were obtained (2007-2008 period Fig. 8a), while in validation the

324 NSE was equal to 0.5250 and RMSE equal to 0.981 for the period 1998-2000 (Fig.8b) and 0.5115 and

3251.032 respectively for the year 1984 (Fig.8c). These modeling results are not extraordinary, but it

326 must be underlined that the objective in this research is the scaling with land use changes, with no

327 particular emphasis on the model performance. Also, it must be taken into account the poor

328 information concerning the precipitation in the upper part of the catchment, as described in section

329 2.1. However, although the regime is different in calibration and validation periods (dryer for 330 calibration), there is not a deterioration in the model efficiency from calibration to validation. Also,

331 existing literature considers acceptable a Nash-Sutcliffe efficiency index greater than 0.5 for

332 validation (Moriasi et al., 2007), which is the case. This is a robust acceptable model implementation, 333 ready to test our hypothesis about flood scaling with land use changes at daily time resolution. 

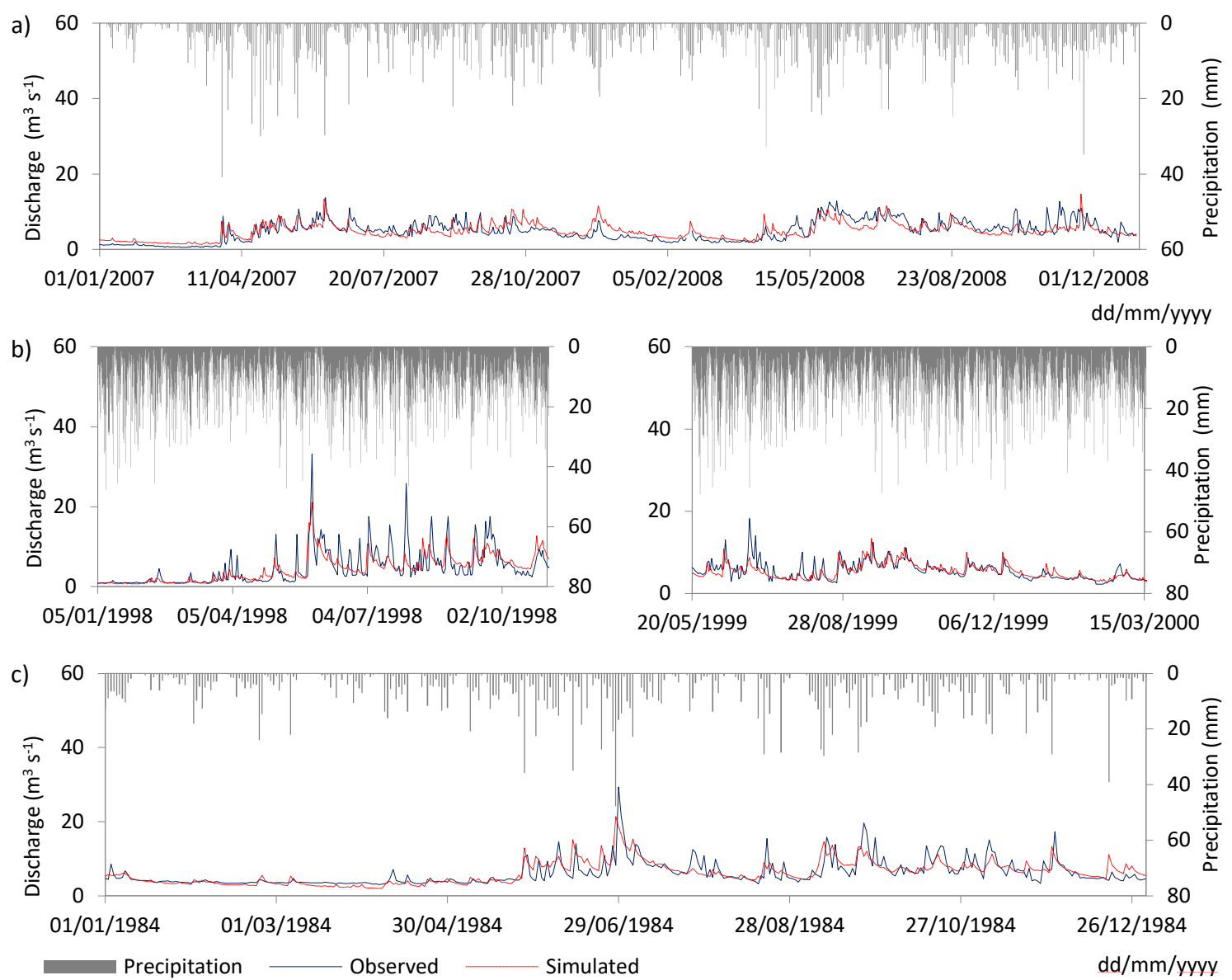

342

343

344

345

346

Fig. 7. Hydrologic model implementation: a) calibration period (2007-2008); b) validation period (1998-2000); c) validation period (1984).

After calibrating and validating the model, simulations of land use changes scenarios were conducted, as described in Section 2.2.3. From the results of these simulations (annual maxima for all land use scenarios can be seen in Fig. 9), it was identified that forests and crops land uses generate lower peak flows than grassland, coinciding with reports by Elfert \& Bormann (2010), mainly due to the associated modal values of the upper soil hydraulic parameters $\mathrm{Hu}$ and $\mathrm{Ks}$ (see the box-plots in Fig. 5c and 5d). Grassland areas increased 37.5\% while forests and crops decreased by 32.1 and $6.2 \%$ respectively between 1991 and 2000 scenarios. These changes produced an increase of $2.1 \%$ on mean annual maximum flow. In the 2007 scenario, forest and crops areas were increased by $7.0 \%$ and $55.9 \%$, while grassland decreased in $30.5 \%$ compared to 2000 scenario. The change from 2000 to 2007 scenario produces a $7.0 \%$ decrease in the maximum annual flows. Similar 

differences were identified in the maximum annual flows comparing 2000 and 2002 scenarios, as

357 reported by Andréassian (2004) and Geris et al. (2015).

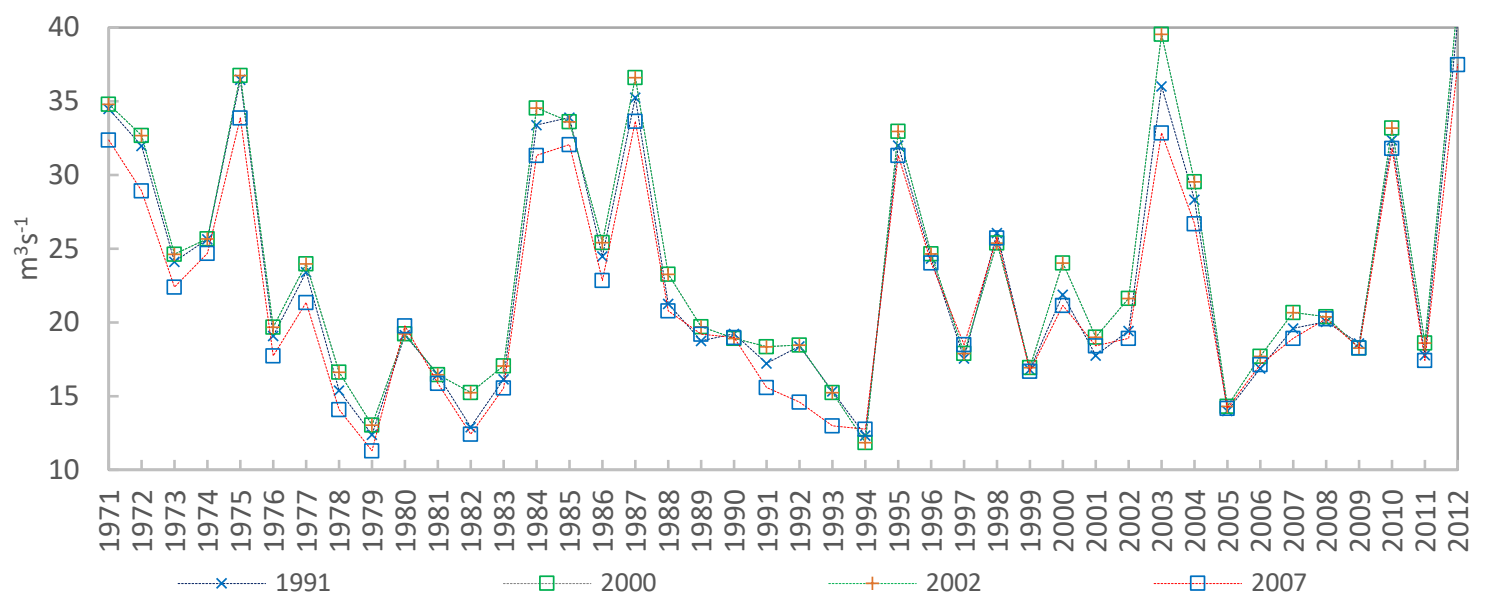

358

359

360

361

362 363

Fig. 8. Maximum annual flows in the Combeima River catchment for the historical land use scenarios.

In scenarios simulating an homogeneous land cover in the catchment (Fig. 10), it was observed more significant changes. The mean maximum annual flow in forest was smaller by $12.4 \%$ than in grassland scenario. Comparing forest and crops scenarios, the annual maximum flows were reduced by $10.3 \%$ in average. On the other hand, for crops and grassland scenarios, an increase of $24.4 \%$ in annual maximum floods was presented in the grassland scenario. Similar results have been reported by Hundecha and Bárdossy (2004), Mao and Cherkauer (2009), Stehr et al. (2010), Udawatta et al. (2002) and Lovell and Sullivan (2006). As can be seen in Fig. 10, the simulation of the Combeima River Land Use Plan gave a similar flood regime to the forest scenario. 


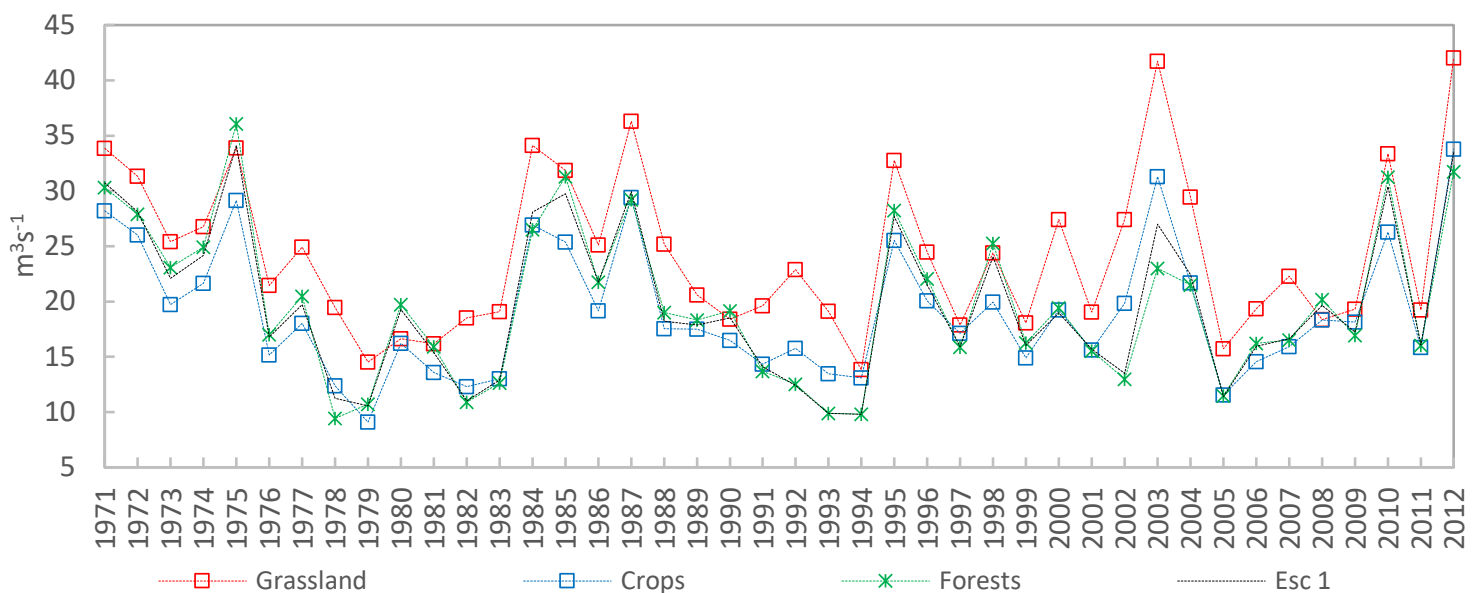

368

369

370

371

372

373

374

375

376

377

378

379

380

381

382

Fig. 9. Maximum annual flows in the Combeima River catchment for the homogeneous and planned (Esc1) land use scenarios.

With the hydrological simulation of homogeneous land covers, it was noted more clearly that annual flow maxima were higher for low $\mathrm{Hu}$ and $\mathrm{Ks}$ values, which are related in the Combeima River catchment to grassland cover (Figs. $5 c$ and $5 d$ ). And the opposite: forest, with higher $\mathrm{Hu}$ and $\mathrm{Ks}$ values, produced less runoff than the crops and grasslands. Thus, the key element to explain the influence of land use changes in this case study is the estimated values of the upper soil hydraulic parameters for each land cover.

\subsection{Flood scaling with $\mathrm{Hu}$ and $\mathrm{Ks}$}

Fig. 11 represents the ordinary $r$ moments of the simulated annual maximum flows, $m_{r}$, as a function of the spatial mean values of $H u$ and $K s$ for the eight land use scenarios. The simulated annual maximum flows are represented in Figs. 9 and 10 and the scenarios are defined in Table 2.

The homogeneous forest, crops and grassland scenarios result left to right points in Fig. 11, respectively. From this figure, it is clear the existence of a power law relationship between $m_{r}$ and the spatial mean of $H u$ and $K s$. In this case, the spatial mean values of $H u$ and $K s$ are acting as the scales ( $\lambda$ in Eqs. 2 and 3) and represent the main effect of different land uses in the flood regime. 
a)

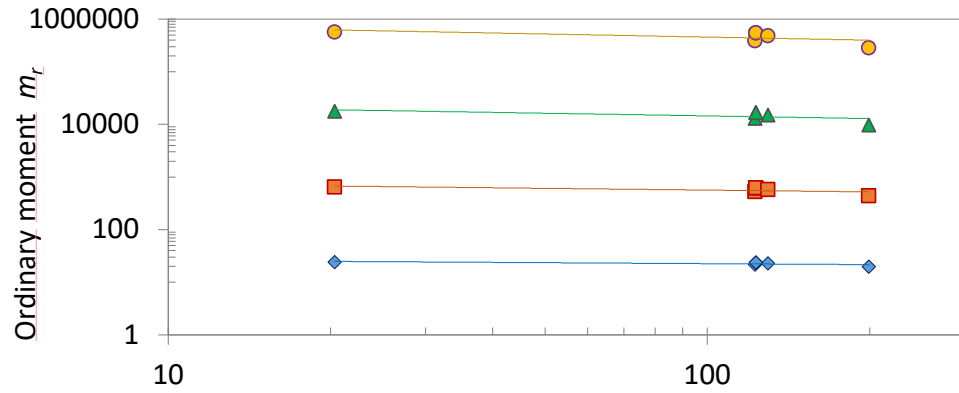

b)

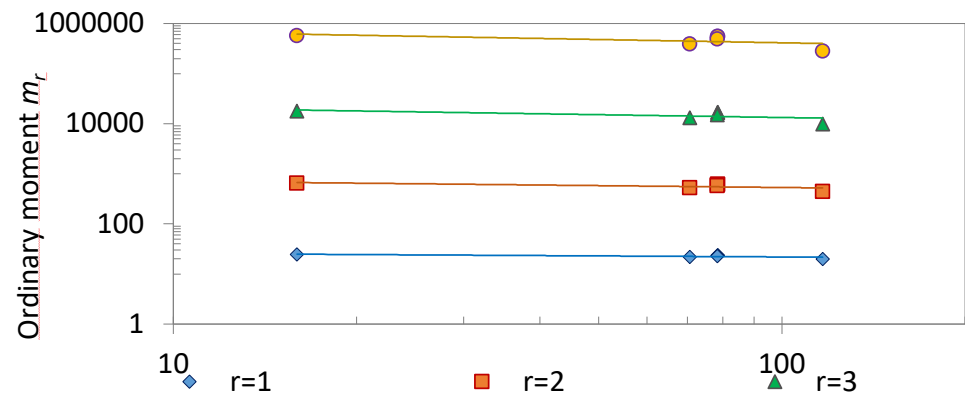

$$
\begin{gathered}
m_{4}=1117654 H u^{-0.195} \\
\mathrm{R}^{2}=0.320 \\
m_{3}=31387 H u^{-0.168} \\
\mathrm{R}^{2}=0.3704 \\
m_{2}=940.71 H u^{-0.111} \\
\mathrm{R}^{2}=0.3913 \\
m_{1}=29.955 H u^{-0.061} \\
\mathrm{R}^{2}=0.4349 \\
H u(\mathrm{~mm})
\end{gathered}
$$

$$
\begin{gathered}
m_{4}=1117670 \mathrm{Ks}^{-0.216} \\
\mathrm{R}^{2}=0.298 \\
m_{3}=31546 \mathrm{Ks}^{-0.188} \\
\mathrm{R}^{2}=0.3492 \\
m_{2}=944.24 \mathrm{Ks}^{-0.124} \\
\mathrm{R}^{2}=0.3695 \\
m_{1}=30.05 \mathrm{Ks}^{-0.069} \\
\mathrm{R}^{2}=0.4139
\end{gathered}
$$

$K s\left(\mathrm{~mm} \mathrm{~h}^{-1}\right)$
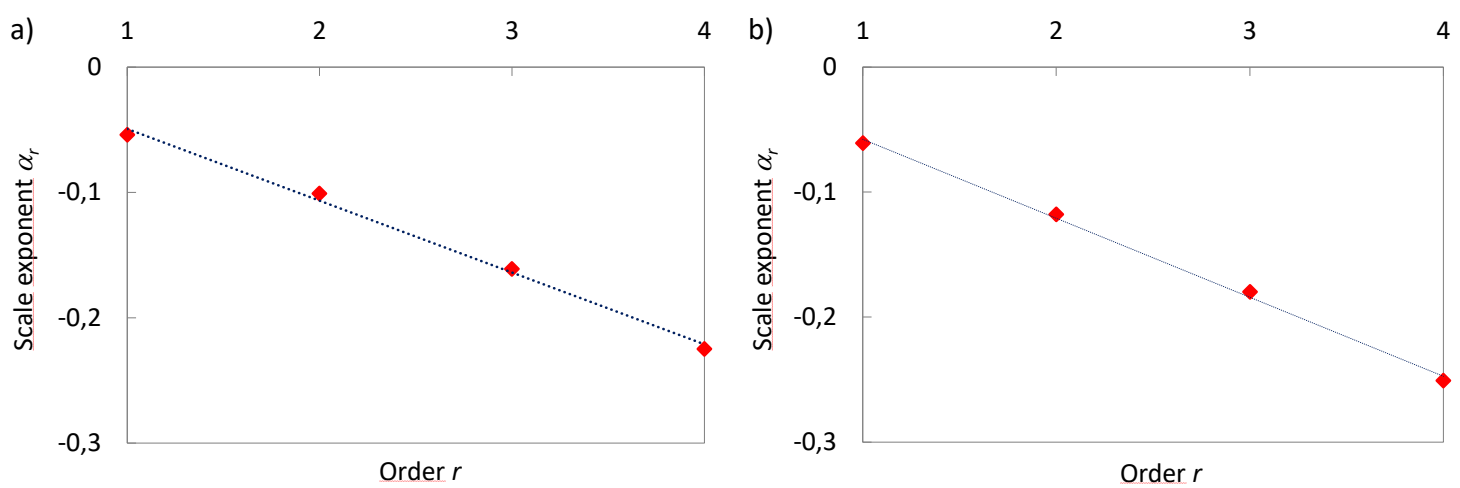

Fig. 10. Testing scaling behavior of upper soil hydraulic properties in the flood regime: a) Static storage capacity $\mathrm{Hu}$; b) Vertical saturated hydraulic conductivity Ks

The slope of each fitted line in Fig. 11 is the estimated value of the scale exponent of each $r$ order.

Fig. 12 represents these scale exponents (different for $\mathrm{Hu}$ and $K s$ ) versus the $r$ order. it is clear the linear dependence defined in Eq. (3) of scale exponents with the $r$ order and it proves the existence of a Wide-Sense Simple Scaling (WSSS), as defined by Gupta \& Waymire (1990), for the annual maximum flows.

Fig. 11. Scale exponent $\alpha_{\mathrm{r}}$ for different $m_{r}$ ordinary moments as a function of $r$ and linear fitting, when scale 


\subsection{Influence of soil heterogeneity in flood scaling}

400 To analyze the effect of the soil spatial heterogeneity, on the hydrological response of the

401 Combeima River catchment and the scaling property, six spatial organization patterns of $\mathrm{Hu}$ and $\mathrm{Ks}$

402 were proposed in the following manner:

403 1) Random spatial distribution (Random)

404 2) Spatial distribution according to the terrain slope (Slope)

405 3) Spatial distribution according to the Beven's Topographic Index (IndTopo)

406 and three spatial dependence based on a semivariogram that describes spherical anisotropy with

407 the same nugget effect $(300 \mathrm{~m})$, sill $(1500 \mathrm{~m})$, range from 2500 to $15000 \mathrm{~m}$, but with different 408 semivariogram angles $\left(0,45\right.$ and $\left.135^{\circ}\right)$ :

409 4) $\gamma(\mathrm{h})=300+1500 \mathrm{Esf}_{15000,2500,0}(A O)$

$410 \quad$ 5) $\gamma(\mathrm{h})=300+1500 \mathrm{Esf}_{15000,2500,135}(A 135)$

411 6) $\gamma(\mathrm{h})=300+1500 \mathrm{Esf}_{15000,2500,45}(A 45)$

412 One example of these different organization patterns can be seen in Fig. 13. For each organization

413 pattern, nine sets of statistics of $H u$ and $K s$ were considered, using three representative (for the

414 three main land covers) mean values $(\mu)$ and three coefficient of variation (CV) (Table 4). A Beta

415 probability distribution function was considered for $\mathrm{Hu}$ values (double bounded), while a Log-

416 Normal distribution (left bounded) was used for Ks values (Barrios \& Francés, 2012). Therefore, for

417 this exercise, $54 \mathrm{Hu}$ and $\mathrm{Ks}$ maps were obtained and the corresponding annual maximum flows were 418 simulated for the complete historical record of meteorological information. 
Table 3. Ks and Hu statistics used for each spatial organization pattern.

\begin{tabular}{|c|c|c|c|c|c|c|c|c|c|}
\hline CV code & $\begin{array}{l}\text { Land } \\
\text { Use }\end{array}$ & $\begin{array}{c}\text { Min } \\
\mathrm{Hu}\end{array}$ & $\begin{array}{l}\mu \\
H u\end{array}$ & $\begin{array}{c}\text { Max } \\
H u\end{array}$ & $\begin{array}{l}\mathrm{CV} \\
\mathrm{Hu}\end{array}$ & $\begin{array}{c}\text { Min } \\
K s\end{array}$ & $\begin{array}{c}\mu \\
K s\end{array}$ & $\begin{array}{c}\text { Max } \\
K s\end{array}$ & $\begin{array}{l}C V \\
K s\end{array}$ \\
\hline CV0.1 & & & 80.31 & & 0.101 & & 70.595 & & 0.101 \\
\hline CV0.3 & Forest & 40.4 & 80.20 & 250.0 & 0.326 & 7.9 & 70.600 & 155.6 & 0.326 \\
\hline CV0.5 & & & 80.54 & & 0.502 & & 70.610 & & 0.501 \\
\hline CV0.1 & & & 48.76 & & 0.102 & & 33.646 & & 0.100 \\
\hline CV0.3 & Crops & 7.9 & 48.76 & 55.2 & 0.326 & 2.0 & 33.627 & 3008.6 & 0.325 \\
\hline CV0.3a & & & 48.77 & & 0.323 & & 33.588 & & 0.500 \\
\hline CV0.1 & & & 20.35 & & 0.102 & & 15.969 & & 0.100 \\
\hline CV0.3 & Grassland & 3.2 & 20.35 & 54.9 & 0.327 & 1.1 & 15.969 & 3000.6 & 0.326 \\
\hline CV0.3a & & & 20.36 & & 0.326 & & 15.957 & & 0.497 \\
\hline
\end{tabular}

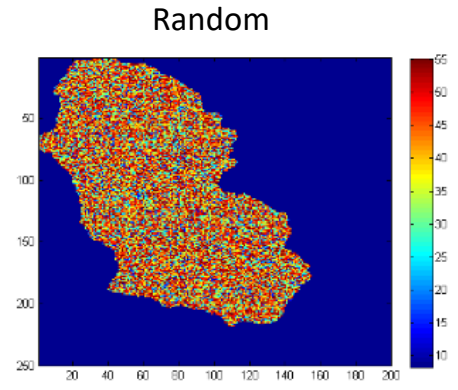

A0

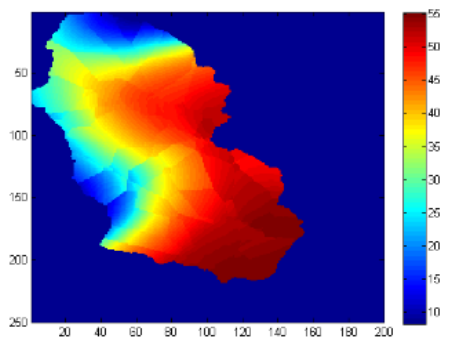

Slope

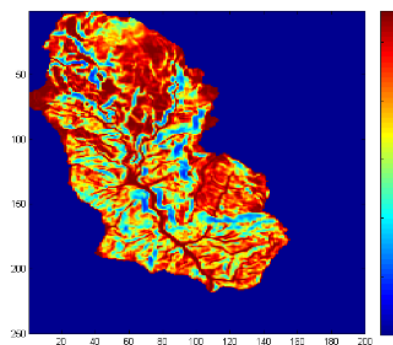

A45

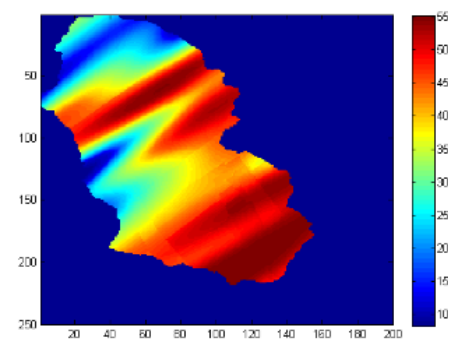

IndTopo

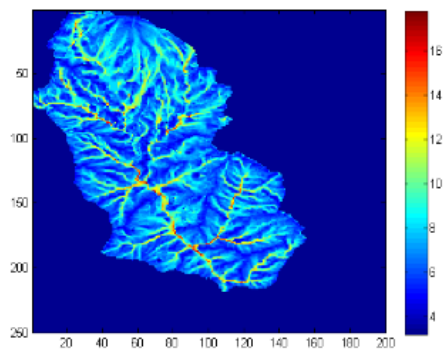

A135

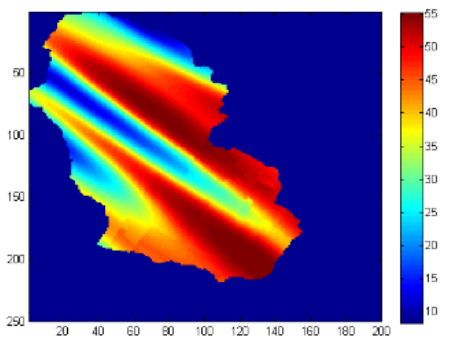

421

422

423

Fig. 12. Hu parameter maps for the six spatial organization patterns in the catchment with mean corresponding to crops and CV equal to 0.3 (CVO3).

Fig. 14 displays the scale exponent for each pattern, land cover and $\mathrm{CV}$ for the parameters $\mathrm{Hu}$ and Ks as a function of moment orders $r$. From this figure, it can be said that there is WSSS independently of the organization pattern, but WSSS will not be possible including all of them. In fact, in Fig. 14, three groups of scaling slopes can be differentiated: 1) those following the organization patterns Slope and IndTopo with a high influence of topography, which have similar slopes for all CVs (from 0.1 to 0.5$) ; 2$ ) patterns based on spherical anisotropy (A0, A45 and A135), which have a lower slope than the previous group; and 3) the Random spatial distribution for CV0.1 has a similar slope to all 
433 for CVO.3a its slope is located within group 1.

434
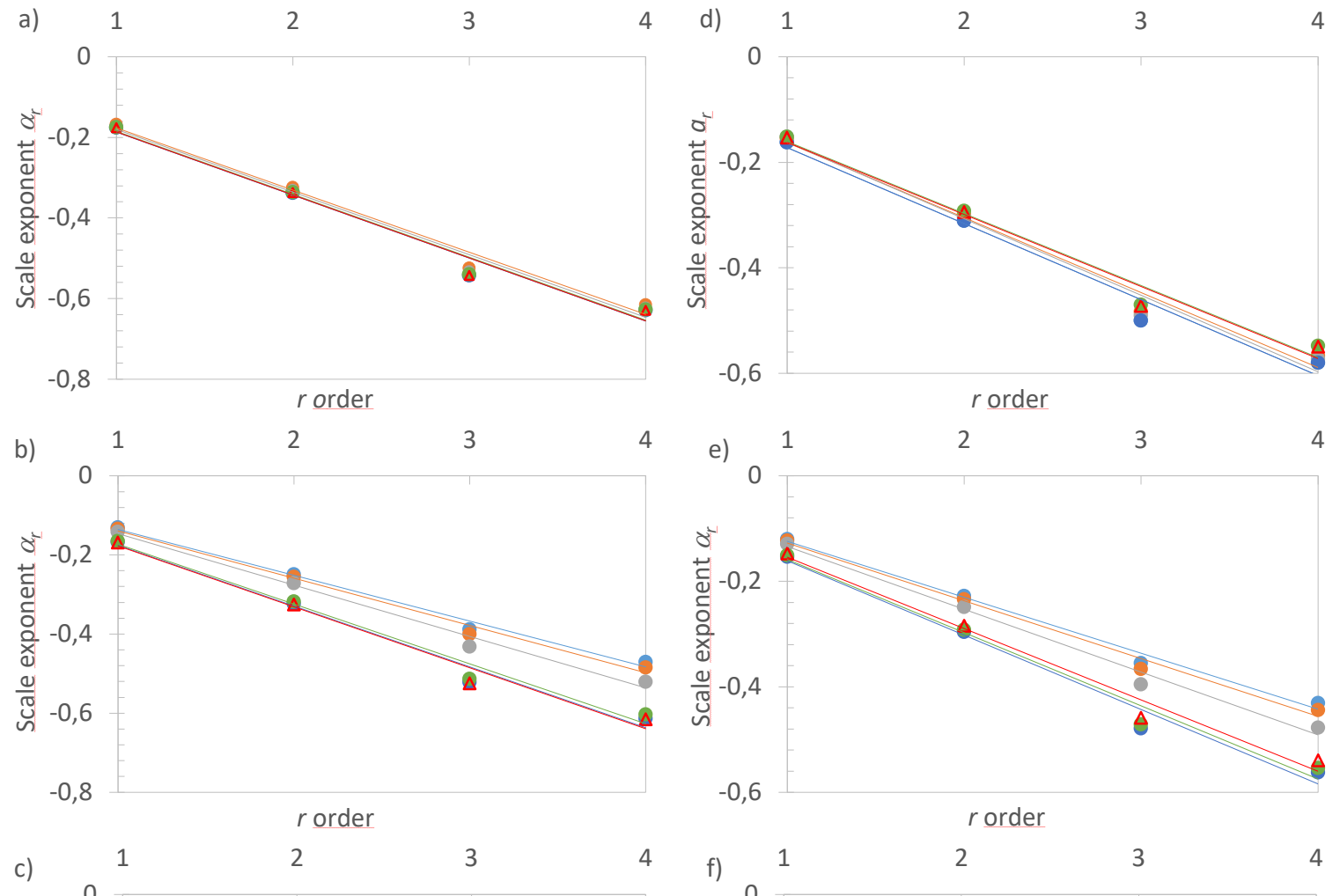

Fig. 13. Scaling exponent $\alpha_{r}$ as a function of moment order $r$ for all spatial organization patterns and land use scenarios for: a) $\mathrm{Hu}$ with $\mathrm{CVO} 0.1$; b) $\mathrm{Hu}$ with $\mathrm{CVO} 0.3$; c) $\mathrm{Hu}$ witn $\mathrm{CVO} 0.5$; d) $\mathrm{Ks}$ with $\mathrm{CVO} .1$; e) $\mathrm{Ks}$ with $\mathrm{CVO} 0.3$; f) $\mathrm{Ks}$ with CV0.3a. Lines are the fitting for each spatial organization pattern.

A high spatial uniformity in the $H u$ and $K s$ values, results in an approximately equal slope of the scale exponents in all the spatial organization patterns scenarios, indicating the strength of the scaling. 
441 This occurs for scenarios with $C V$ values of 0.1 (Figs. 14a and d). On the contrary, it can be observed

442 that when the spatial heterogeneity of the $H u$ and $K s$ parameters is high (Figs. $14 b, c$, $d$ and f), the 443 slopes of the scaling exponent are lower, which indicates the scaling is weaker (Burlando \& Rosso, 444 1996). Therefore, it may be stated that the spatial organization of the parameters does not affect 445 the existence of scaling, but it will be different and the spatial heterogeneity of the soil hydraulic 446 properties determines the strength of the WSSS.

447

\subsection{Scaling of the GEV distribution parameters}

449 The GEV distribution function was applied to analyze flood frequency in scenarios of land use 450 changes and test the possibility of scaling of its parameters. Table 5 and Fig. 15 resume the results 451 of this analysis. From the statistical point of view, it can be seen that all land use scenarios have 452 similar ML values, which means a similar fitting performance.

453 Concerning the impact of land use changes, it must be taken into account the uncertainty associated 454 to the estimated quantiles (only 42 years of simulated series) and, therefore, is not possible to 455 address absolute conclusions. But it can be said that in scenarios of homogeneous crops and forest 456 resulted in lower magnitudes of the maximum flows and flood quantiles compared to grasslands or 457 land use scenarios with a high percentage of pastures, as in scenarios 2000 and 2002 . These results 458 are similar to those found by Kumar et al. (2008), Elfert \& Bormann (2010), Nie et al. (2011) and 459 Salazar et. (2012). Also, it can be mentioned from Fig. 15 that the flood regime of land use planning 460 scenario (Esc1) is more similar to a homogeneous forest land cover, and the historical land use 461 scenarios are more similar to the grassland scenario. Different land uses can change significantly the

462 flood regime depending on the intensity of the land use change and the case study: for example, 
464 to $53 \mathrm{~m}^{3} / \mathrm{s}$ (a $40 \%$ difference).

465 466

Table 4. For each land use scenario, spatial mean of the upper soil hydraulic parameters, flood sample statistics and parameters and flood quantiles using the GEV.

\begin{tabular}{|c|c|c|c|c|c|c|c|c|c|c|c|c|c|c|c|}
\hline \multirow{3}{*}{$\begin{array}{c}\text { Land } \\
\text { use } \\
\text { scenario }\end{array}$} & \multicolumn{2}{|c|}{$\begin{array}{c}\text { Upper soil } \\
\text { parameters }\end{array}$} & \multicolumn{4}{|c|}{ Flood sample statistics } & \multicolumn{4}{|c|}{ ML GEV parameters } & \multicolumn{5}{|c|}{ Flood quantiles $\left(\mathrm{m}^{3} / \mathrm{s}\right)$} \\
\hline & \multirow{2}{*}{ Hu } & \multirow{2}{*}{ Ks } & \multirow{2}{*}{$\mu$} & \multirow{2}{*}{$\eta$} & \multirow{2}{*}{$\gamma$} & \multirow{2}{*}{$\mathbf{k}$} & \multirow[b]{2}{*}{$\beta$} & \multirow[b]{2}{*}{$\alpha$} & \multirow[b]{2}{*}{$\kappa$} & \multirow{2}{*}{$\begin{array}{l}\text { Maximum } \\
\text { Likelihood }\end{array}$} & \multicolumn{5}{|c|}{ Return period (years) } \\
\hline & & & & & & & & & & & 5 & 10 & 25 & 50 & 100 \\
\hline 2007 & 122.748 & 70.599 & 21.786 & 0.325 & 0.601 & 2.079 & -0.047 & 5.388 & 18.379 & -138.506 & 26.754 & 31.174 & 36.988 & 41.473 & 46.075 \\
\hline 2002 & 123.111 & 78.534 & 23.537 & 0.334 & 0.738 & 2.275 & -0.109 & 5.644 & 19.67 & -141.705 & 28.869 & 34.069 & 41.281 & 47.135 & 53.408 \\
\hline 2000 & 123.111 & 78.534 & 23.537 & 0.334 & 0.738 & 2.275 & -0.109 & 5.645 & 19.673 & -141.705 & 28.871 & 34.069 & 41.276 & 47.125 & 53.392 \\
\hline 1991 & 129.699 & 78.38 & 22.79 & 0.337 & 0.705 & 2.157 & -0.129 & 5.416 & 18.902 & -140.652 & 27.862 & 33.036 & 40.331 & 46.346 & 52.881 \\
\hline Esc1 & 163.436 & 92.121 & 19.758 & 0.348 & 0.482 & 2.068 & 0.05 & 5.672 & 16.681 & -138.368 & 24.879 & 28.757 & 33.456 & 36.801 & 40.008 \\
\hline Forest & 199.472 & 116.676 & 19.778 & 0.352 & 0.466 & 2.223 & 0.094 & 5.923 & 16.801 & -139.098 & 25.086 & 28.813 & 33.161 & 36.145 & 38.918 \\
\hline Crops & 48.88 & 33.634 & 19.117 & 0.31 & 0.748 & 2.553 & -0.014 & 4.58 & 16.39 & -130.75 & 23.33 & 26.855 & 31.361 & 34.742 & 38.129 \\
\hline Grassland & 20.367 & 15.971 & 24.316 & 0.3 & 0.77 & 2.559 & -0.106 & 5.232 & 20.696 & -138.613 & 29.201 & 33.991 & 40.613 & 45.974 & 51.705 \\
\hline
\end{tabular}

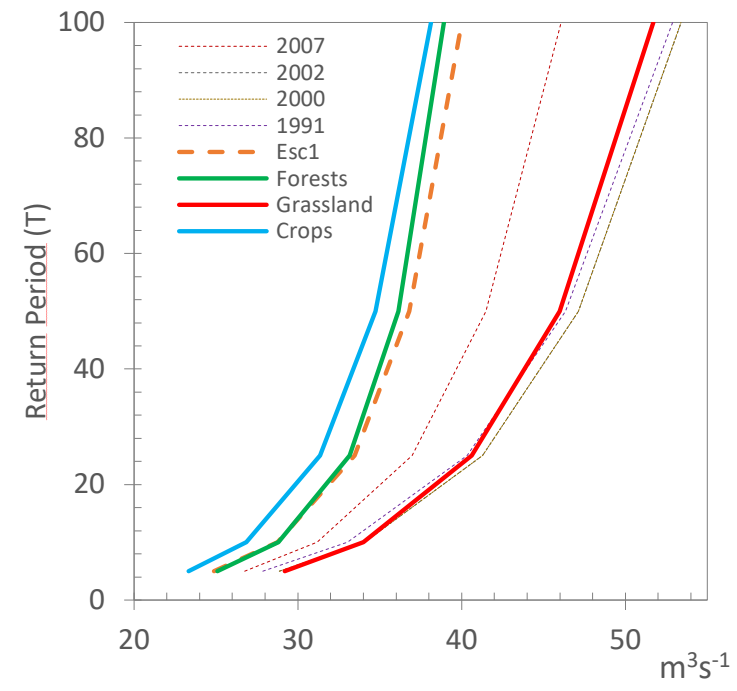

Fig. 14. Estimated flood quantiles using the GEV distribution for all land use scenarios.

471

472 Fig. 16 shows, that the $\alpha$ and $\kappa$ GEV parameters follow a power law with respect to the upper soil

473 hydraulic properties, as described by Eqs. 5 and 6. The fitted equations are given in this figure. On 474 the other hand, there are negative values for the estimated $\beta$ values, which is incompatible with a 
475 power law (Figs. $16 \mathrm{~b}$ and e). However, the actual magnitude of floods makes the estimated $\beta \mathrm{s}$

476 relatively close to zero, and the equation $\beta_{\lambda}=0$ is a special case of power law. A GEV with null $\beta$

477 collapses into a Weibull distribution and, at the same time, the WSSS property is satisfied.
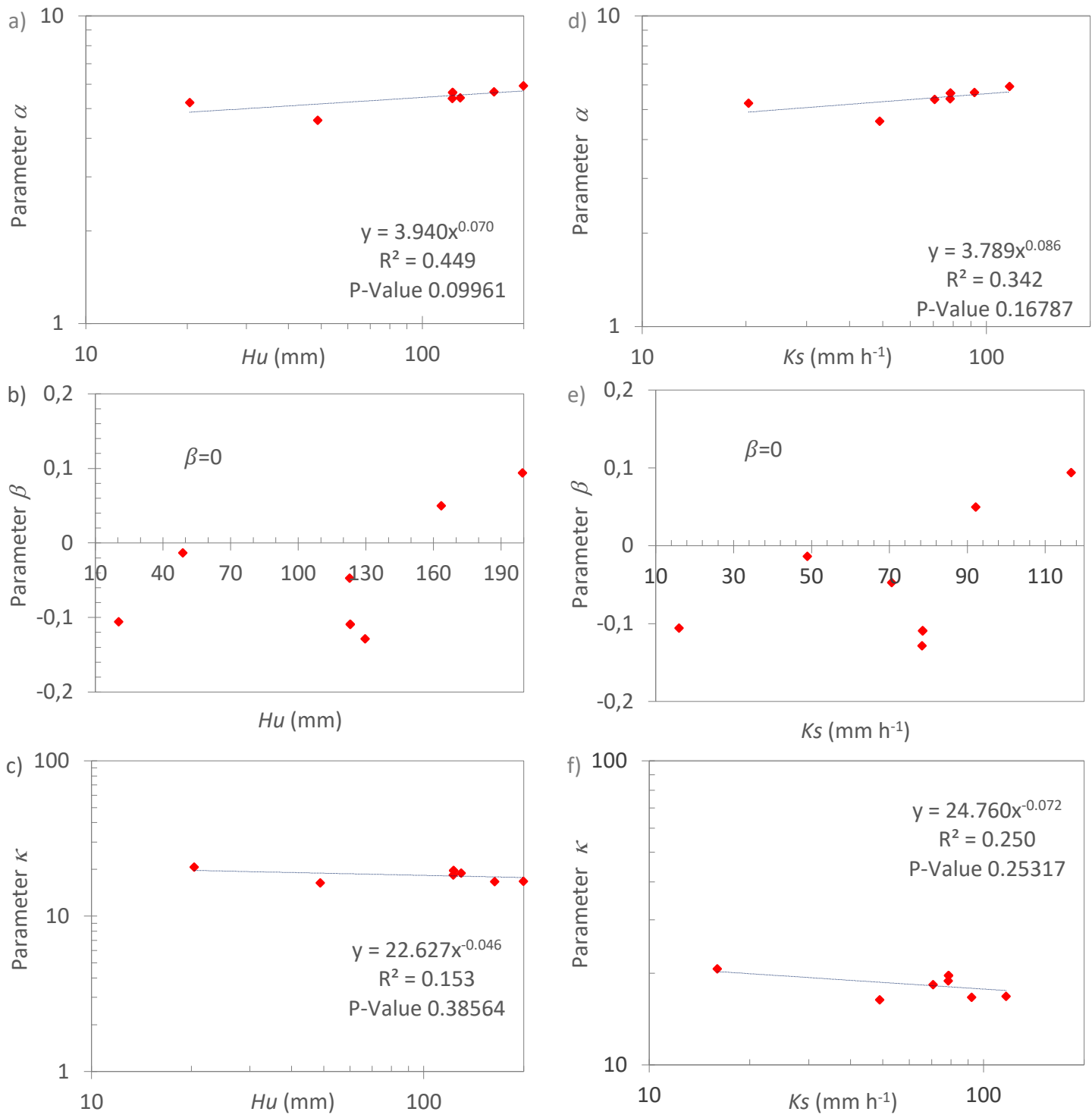

Fig. 15. Scaling behavior of GEV distribution parameters: $a, b, c)$ scale, location and shape respectively for Hu; d, e, f) idem for $K s$.

It is clear that in some cases the regressions are relatively strong (maximum R2 equal to 0.45) and in others are weak (minimum R2 equal to 0.15). In terms of p-values the equivalent are 0.1 and 0.39 respectively. In terms of critical values for correlation the critical values are 0.582 for $\alpha=0.1$ and 0.754 for $\alpha=0.05$. Of course these numbers are not showing a perfect scaling of the GEV parameters, but working with real Nature these regressions can be acceptable. 


\section{Conclusions}

487 Land use change scenarios are reflected in the hydrological model TETIS by changes in

488 evapotranspiration and runoff production parameters. In particular, for flood regime

489 characterization, its upper soil hydraulic parameters $\mathrm{Hu}$ and $\mathrm{Ks}$ are the more important

490 characteristics. Given that this study adopted modal values for $\mathrm{Hu}$ and $\mathrm{Ks}$ using pedotransfer

491 functions, more research is needed to contrast the results presented in this paper with empirical

492 values of the evolution and change of upper soil hydraulic properties with land use changes.

493 Through hydrological simulation of different land use scenarios in the Combeima River catchment

494 for the whole historical period 1971-2012, it was found that annual maximum flows and flood

495 quantiles can be sensible to land use changes, depending on the intensity of the land use change. In

496 this case study, floods presented higher magnitudes for grassland cover and lower for forests and

497 crops land uses. Or vice versa: transitions from grasslands to forests or crops could reduce floods

498 magnitude. However, in some cases it may not have a significant effect on the magnitude of annual

499 flow maxima, as observed in Combeima River catchment if 2000 and 2002 scenarios are compared.

500 For each land use scenario, sample ordinary moments were estimated from the 42 years of

501 simulated maximum annual flows. It was clear that ordinary moments are invariant using as scale

502 the catchment spatial mean of $H u$ and Ks. Actually, the scaling can be considered Wide-Sense Simple

503 Scaling (WSSS) due to the linear relationship between the scale exponents of the ordinary $r$

504 moments and the moment order $m_{r}$.

505 The effect of the spatial variability of the upper soil hydraulic properties within the catchment area

506 was evaluated through the simulation of different spatial organization patterns. It was found that

507 spatial pattern influences the flood behavior, but maintaining the WSSS property. In other words, 
508 floods are fractals with the appropriated scale related with the main runoff production 509 characteristics at catchment scale.

510 Scalable behavior was also found in the parameters of the fitted GEV distribution to the simulated

511 annual maxima, in relation to the catchment spatial mean of $H u$ and $K s$ parameters. Moreover,

512 through the determination of $\mathrm{Hu}$ and $\mathrm{Ks}$ for different land use scenarios, it is possible to obtain flood

513 quantiles by exploiting the WSSS with a minimum of simulations. This could represent a very

514 valuable tool for environmental planning and flood risk management at catchment scale, especially

515 in areas with scarce or no hydrometric information.

517 Acknowledgements. This research was funded partially by the COLCIENCIAS 567 doctoral fellowship program, Universidad 518 del Tolima project 1300213 and Universidad de Ibagué (Colombia) project 12-262-COL00, and by Universitat Politècnica 519 de València (Spain) and by the Spanish Research Project ECO-TETIS (ref. CGL2011-28776-C02-01) and TETIS-MED (ref. 520 CGL2014-58127-C3-3-R). Thanks to The Shuttle Radar Topography Mission NASA, IDEAM and IGAC in Colombia, for 521 providing digital elevation model, streamflow, rainfall data, and soil study of the Tolima Region.

522

523 Appendix A. GEV parameter estimation by ML method

524 Estimation of GEV parameters through ML method is done in this research solving the next system 525 of non-linear equations:

$526 \quad \frac{1}{\alpha} \sum_{i=1}^{N}\left[\frac{1-k-\left(Y_{i}\right)^{1 / k}}{Y_{i}}\right]=0$

$527-\frac{N}{\alpha}+\frac{1}{\alpha} \sum_{i=1}^{N}\left[\frac{1-k-\left(Y_{i}\right)^{1 / k}}{Y_{i}}\left(\frac{Y_{i}-\beta}{\alpha}\right)\right]=0$

$528-\frac{1}{k^{2}} \sum_{i=1}^{N}\left\{\ln Y_{i}\left[1-k-\left(Y_{i}\right)^{\frac{1}{k}}\right]+\frac{1-k-\left(Y_{i}\right)^{\frac{1}{k}}}{Y_{i}} k\left(\frac{Y_{i}-\beta}{\alpha}\right)\right\}=0$

529 The convergence criterion for each of these equations is given respectively by: 

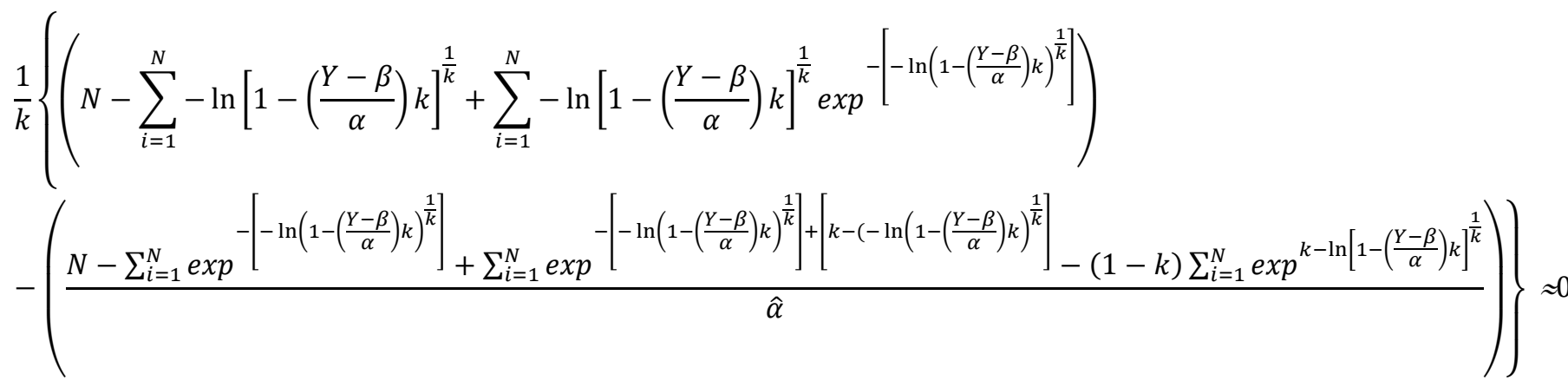

\section{References}

Abrahams, A. D., Parsons, A. J., \& Wainwright, J. (1995). Effects of vegetation change on interrill runoff and erosion, Walnut Gulch, southern Arizona. Geomorphology, 13(1-4), 37-48. doi:10.1016/0169-555X(95)00027-3 Sicilian Watershed. Soil Science Society of America Journal, 75(5), 1958. doi:10.2136/sssaj2011.0044

Alaoui, A., Willimann, E., Jasper, K., Felder, G., Herger, F., Magnusson, J., \& Weingartner, R. (2014). Modelling the effects of land use and climate changes on hydrology in the Ursern Valley, Switzerland. Hydrological Processes, 28(10), 3602-3614. doi:10.1002/hyp.9895

Allen, R. G., Pereira, L. S., Raes, D., \& Smith, M. (1998). Crop evapotranspiration: Guidelines for computing crop requirements. Irrigation and Drainage Paper No. 56, FAO. doi:10.1016/j.eja.2010.12.001

Andréassian, V. (2004). Waters and forests: From historical controversy to scientific debate. Journal of Hydrology, (291), 1-27. doi:10.1016/j.jhydrol.2003.12.015

Andrés-Doménech, I., Múnera, J. C., Francés, F., \& Marco, J. B. (2010). Coupling urban event-based and catchment continuous modelling for combined sewer overflow river impact assessment. Hydrology and Earth System Sciences, 14, 2057-2072. doi:10.5194/hess-14-2057-2010

Barrios, M., \& Francés, F. (2012). Spatial scale effect on the upper soil effective parameters of a distributed hydrological model. Hydrological Processes, 26(7), 1022-1033. doi:10.1002/hyp.8193

Bhattacharyya, R., Prakash, V., Kundu, S., \& Gupta, H. S. (2006). Effect of tillage and crop rotations on pore size distribution and soil hydraulic conductivity in sandy clay loam soil of the Indian Himalayas. Soil and Tillage Research, 86(2), 129140. doi:10.1016/j.still.2005.02.018

Botero, B. A., \& Francés, F. (2010). Estimation of high return period flood quantiles using additional non-systematic information with upper bounded statistical models. Hydrology and Earth System Sciences, 14(12), 2617-2628. doi:10.5194/hess-14-2617-2010

Bronstert, A. (2003). Floods and climate change: interactions and impacts. Risk Analysis : An Official Publication of the Society for Risk Analysis, 23(3), 545-57. Retrieved from http://www.ncbi.nlm.nih.gov/pubmed/12836847

Burlando, P., \& Rosso, R. (1996). Scaling and multiscaling models of depth-duration-frequency curves for storm precipitation. Journal of Hydrology, 187, 45-64. doi:10.1016/S0022-1694(96)03086-7

Burn, D. H., \& Whitfield, P. H. (2015). Changes in floods and flood regimes in Canada. Canadian Water Resources Journal / Revue Canadienne Des Ressources Hydriques, (August 2015), 1-12. doi:10.1080/07011784.2015.1026844 
Bussi, G., Frances, F., Montoya, J. J., \& Julien, P. Y. (2014). Distributed sediment yield modelling: Importance of inicial sediment conditions. Environmental Modelling and Software, (58), 58-70.

Chen, X., Zhang, Z., Chen, X., \& Shi, P. (2009). The impact of land use and land cover changes on soil moisture and hydraulic conductivity along the karst hillslopes of southwest China. Environmental Earth Sciences, 59(4), 811-820. doi:10.1007/s12665-009-0077-6

Cornelissen, T., Diekkrüger, B., \& Giertz, S. (2013). A comparison of hydrological models for assessing the impact of land use and climate change on discharge in a tropical catchment. Journal of Hydrology, 498, 221-236. doi:10.1016/j.jhydrol.2013.06.016

De Michele, C., \& Salvadori, G. (2002). On the derived flood frequency distribution : analytical formulation and the in fluence of antecedent soil moisture condition. Journal of Hydrology, 262, 245-258. doi:10.1016/S00221694(02)00025-2

Duan, Q., Sorooshian, S., \& Gupta, V. (1994). Optimal use of the SCE-UA global optimization method for calibrating watershed models. Journal of Hydrology, 158(3-4), 265-284. doi:10.1016/0022-1694(94)90057-4

Eckhardt, K., Breuer, L., \& Frede, H. (2003). Parameter uncertainty and the significance of simulated land use change effects. Journal of Hydrology, 273(1-4), 164-176. doi:10.1016/s0022-1694(02)00395-5

Elfert, S., \& Bormann, H. (2010). Simulated impact of past and possible future land use changes on the hydrological response of the Northern German lowland "Hunte" catchment. Journal of Hydrology, 383(3-4), $245-255$. doi:10.1016/j.jhydrol.2009.12.040

Francés, F., Vélez, J. I., \& Vélez, J. J. (2007). Split-parameter structure for the automatic calibration of distributed hydrological models. Journal of Hydrology, 332(1-2), 226-240. doi:10.1016/j.jhydrol.2006.06.032

García, B., Peña, L. E., Barrios, M., \& Múnera, J. (2016). Uncertainty of discharge estimation in high-grade Andean streams. Flow Measurement and Instrumentation, 48, 42-50. doi:10.1016/j.flowmeasinst.2016.02.005

Geris, J., O'Connell, E., Greg, O., \& Will, M. (2015). Multiscale experimentation, monitoring and analysis of long-term land use changes and flood risk - SC060092/R1. Bristol, UK.: Environment Agency. Retrieved from https://www.gov.uk/government/uploads/system/uploads/attachment_data/file/480785/Land_use_change_and _flood_risk_report.pdf

Ghaffari, G., Keesstra, S., Ghodousi, J., \& Ahmadi, H. (2010). SWAT-simulated hydrological impact of land-use change in the Zanjanrood Basin, Northwest Iran. Hydrological Processes, 24, 892-903. doi:10.1002/hyp.7530

GREHYS, G. de recherche en hydrologie statistique. (1996). Presentation and review of some methods for regional flood frequency analysis. Journal of Hydrology.

Gupta, S., Mohanty, B. P., \& Köhne, M. (2006). Soil Hydraulic Conductivities and their Spatial and Temporal Variations in a Vertisol. Soil Science Society of America Journal, 70(6), 1872. doi:10.2136/sssaj2006.0201

Gupta, V. K., \& Waymire, E. (1990). Multiscaling properties of spatial rainfall and river flow distributions. Journal of Geophysical Research, 95(D3), 1999. doi:10.1029/JD095iD03p01999

Hopmans, J. W., Nielsen, D. R., \& Bristow, K. L. (2002). How useful are small-scale soil hydraulic property measurements for large-scale vadose zone modeling? Geophysical Monograph Series, 129, 247-258. doi:10.1029/129GM20

Hu, W., Shao, M., Wang, Q., Fan, J., \& Horton, R. (2009). Temporal changes of soil hydraulic properties under different land uses. Geoderma, 149(3-4), 355-366. doi:10.1016/j.geoderma.2008.12.016

Hundecha, Y., \& Bárdossy, A. (2004). Modeling of the effect of land use changes on the runoff generation of a river basin through parameter regionalization of a watershed model. Journal of Hydrology, 292, 281-295. doi:10.1016/j.jhydrol.2004.01.002

Jung, I. W., Chang, H., \& Moradkhani, H. (2011). Quantifying uncertainty in urban flooding analysis considering hydroclimatic projection and urban development effects. Hydrology and Earth System Sciences, 15(2), $617-633$. doi:10.5194/hess-15-617-2011

Kodesová, R., Jirku, V., Kodes, V., Muhlhanselová, M., Nikodem, A., \& Žigová, A. (2011). Soil structure and soil hydraulic properties of Haplic Luvisol used as arable land and grassland. Soil and Tillage Research, 111(2), $154-161$. doi:10.1016/j.still.2010.09.007

Koinig, K., Shotyk, W., Lotter, A., \& Ohlendorf, C. (2003). 9000 years of geochemical evolution of lithogenic major and trace elements in the sediment of an .... Journal of Paleolimnology, 30, 307-320. Retrieved from http://www.springerlink.com/index/G548V1W32W731523.pdf(nfile:///Users/whobbs/Documents/PDFs/Papers2 /Koinig/2003/J Paleolimnol $2003 \quad$ Koinig.pdf $\backslash n$ papers2://publication/uuid/OAOCA68B-51CB-426B-AEC416055B490C9D

Kumar, S., Anderson, S. H., Bricknell, L. G., Udawatta, R. P., \& Gantzer, C. J. (2008). Soil hydraulic properties influenced by agroforestry and grass buffers for grazed pasture systems. Journal of Soil and Water Conservation, 63(4), $224-232$. doi:10.2489/63.4.224

Kuraś, P. K., Alila, Y., \& Weiler, M. (2012). Forest harvesting effects on the magnitude and frequency of peak flows can increase with return period. Water Resources Research, 48(1), 1-19. doi:10.1029/2011WR010705

Lovell, S. T., \& Sullivan, W. C. (2006). Environmental benefits of conservation buffers in the United States: Evidence, promise, and open questions. Agriculture, Ecosystems and Environment, 112(4), 249-260. 
doi:10.1016/j.agee.2005.08.002

Mao, D., \& Cherkauer, K. a. (2009). Impacts of land-use change on hydrologic responses in the Great Lakes region. Journal of Hydrology, 374, 71-82. doi:10.1016/j.jhydrol.2009.06.016

Marshall, M. R., Ballard, C. E., Frogbrook, Z. L., Solloway, I., Mcintyre, N., Reynolds, B., \& Wheater, H. S. (2014). The impact of rural land management changes on soil hydraulic properties and runoff processes: Results from experimental plots in upland UK. Hydrological Processes, 28(4), 2617-2629. doi:10.1002/hyp.9826

McCormick, B. C., Eshleman, K. N., Griffith, J. L., \& Townsend, P. a. (2009). Detection of flooding responses at the river basin scale enhanced by land use change. Water Resources Research, 45(8), 1-15. doi:10.1029/2008WR007594

Moriasi, D. N., Arnold, J. G., Van Liew, M. W., Binger, R. L., Harmel, R. D., \& Veith, T. L. (2007). Model evaluation guidelines for systematic quantification of accuracy in watershed simulations. Transactions of the ASABE, 50(3), 885-900. doi:10.13031/2013.23153

Morrison, J. E., \& Smith, J. a. (2002). Stochastic modeling of flood peaks using the generalized extreme value distribution. Water Resources Research, 38(12), 41-1-41-12. doi:10.1029/2001WR000502

Nie, W., Yuan, Y., Kepner, W., Nash, M. S., Jackson, M., \& Erickson, C. (2011). Assessing impacts of Landuse and Landcover changes on hydrology for the upper San Pedro watershed. Journal of Hydrology, 407(1-4), $105-114$. doi:10.1016/j.jhydrol.2011.07.012

Niemeyer, R. J., Fremier, a. K., Heinse, R., Chávez, W., \& DeClerck, F. a. J. (2014). Woody Vegetation Increases Saturated Hydraulic Conductivity in Dry Tropical Nicaragua. Vadose Zone Journal, 13(1). doi:10.2136/vzj2013.01.0025

Öztürk, M., Copty, N. K., \& Saysel, A. K. (2013). Modeling the impact of land use change on the hydrology of a rural watershed. Journal of Hydrology, 497, 97-109. doi:10.1016/j.jhydrol.2013.05.022

Quilbé, R., Rousseau, a. N., Moquet, J.-S., Savary, S., Ricard, S., \& Garbouj, M. S. (2008). Hydrological responses of a watershed to historical land use evolution and future land use scenarios under climate change conditions. Hydrology and Earth System Sciences, 12, 101-110. doi:10.5194/hess-12-101-2008

Rivera, M. (2008). Determinación de la dinámica del agua en el sistema agroforestal Quesungual e identificación de factores suelo-planta para el mejoramiento de la productividad del agua en los cultivos. Universidad Nacional de Colombia. Retrieved from http://www.bdigital.unal.edu.co/706/

Robinson, J. S., \& Sivanapalan, M. (1997). Temporal scales and hydrological regimes : Implications for flood frequency scaling interactions can help identify different hydrological Using the theoretical regimes are characterized by low values of the coefficient of variation, peaks, while fast re, 33(12), 2981-2999.

Robinson, M., Cognard-Plancq, A. L., Cosandey, C., David, J., Durand, P., F??hrer, H. W., ... Zollner, A. (2003). Studies of the impact of forests on peak flows and baseflows: A European perspective. Forest Ecology and Management, 186(13), 85-97. doi:10.1016/S0378-1127(03)00238-X

Ruiz-Villanueva, V., Stoffel, M., Bussi, G., Francés, F., \& Bréthaut, C. (2015). Climate change impacts on discharges of the Rhone River in Lyon by the end of the twenty-first century: model results and implications. Regional Environmental Change, 15(3), 505-515. doi:10.1007/s10113-014-0707-8

Sajikumar, N., \& Remya, R. S. (2014). Impact of land cover and land use change on runoff characteristics. Journal of Environmental Management, 1-9. doi:10.1016/j.jenvman.2014.12.041

Salazar, S., Francés, F., Komma, J., Blume, T., Francke, T., Bronstert, a., \& Blöschl, G. (2012). A comparative analysis of the effectiveness of flood management measures based on the concept of "retaining water in the landscape" in different European hydro-climatic regions. Natural Hazards and Earth System Science, 12(11), 3287-3306. doi:10.5194/nhess-12-3287-2012

Salemi, L. F., Groppo, J. D., Trevisan, R., de Moraes, J. M., de Barros Ferraz, S. F., Villani, J. P., ... Martinelli, L. A. (2013). Land-use change in the Atlantic rainforest region: Consequences for the hydrology of small catchments. Journal of Hydrology, 499, 100-109. doi:10.1016/j.jhydrol.2013.06.049

Saxton, K. E., \& Rawls, W. J. (2006). Soil Water Characteristic Estimates by Texture and Organic Matter for Hydrologic Solutions. Soil Science Society of America Journal, 70(5), 1569. doi:10.2136/sssaj2005.0117

Schwärzel, K., Carrick, S., Wahren, A., Feger, K.-H., Bodner, G., \& Buchan, G. (2011). Soil Hydraulic Properties of Recently Tilled Soil under Cropping Rotation Compared with Two-Year Pasture. Vadose Zone Journal, 10(1), 354. doi:10.2136/vzj2010.0035

Srinivas, V. V., Tripathi, S., Rao, a. R., \& Govindaraju, R. S. (2008, January). Regional flood frequency analysis by combining self-organizing feature map and fuzzy clustering. Journal of Hydrology. doi:10.1016/j.jhydrol.2007.09.046

Stehr, a., Aguayo, M., Link, O., Parra, O., Romero, F., \& Alcayaga, H. (2010). Modelling the hydrologic response of a mesoscale Andean watershed to changes in land use patterns for environmental planning. Hydrology and Earth System Sciences, 14(10), 1963-1977. doi:10.5194/hess-14-1963-2010

Udawatta, R. P., Krstansky, J. J., Henderson, G. S., \& Garrett, H. E. (2002). Agroforestry practices, runoff, and nutrient loss: a paired watershed comparison. Journal of Environmental Quality, 31(4), 1214-1225. doi:10.2134/jeq2002.1214

Vaskôva, I. (2001). Cálculo de las curvas IDF mediante la incorporación de las propiedades de escala y de dependencia temporales. Universitat Politècnica de València.

Vélez, J. J., Puricelli, M., López Unzu, F., \& Francés, F. (2009). Parameter extrapolation to ungauged basins with a 
hydrological distributed model in a regional framework. Hydrology and Earth System Sciences Discussions, 13, 229246. doi:10.5194/hessd-4-909-2007

Villarini, G. (2010). Analysis of the stationarity of flood peaks in the United States. In Workshop on Nonstationarity, Hydrologic Frequency Analysis, and Water Management (pp. 81-97). Retrieved from www.cwi.colostate.edu

Whitfield, P. H. (2012). Floods in future climates: A review. Journal of Flood Risk Management, 5(4), $336-365$. doi:10.1111/j.1753-318X.2012.01150.x

Wijesekara, G. N., Gupta, a., Valeo, C., Hasbani, J. G., Qiao, Y., Delaney, P., \& Marceau, D. J. (2012). Assessing the impact of future land-use changes on hydrological processes in the Elbow River watershed in southern Alberta, Canada. Journal of Hydrology, 412-413, 220-232. doi:10.1016/j.jhydrol.2011.04.018

Zhang, Y., Smith, J. a., \& Baeck, M. L. (2001). The hydrology and hydrometeorology of extreme floods in the Great Plains of Eastern Nebraska. Advances in Water Resources, 24, 1037-1049. doi:10.1016/S0309-1708(01)00037-9

Zhou, X., Lin, H. S., \& White, E. a. (2008). Surface soil hydraulic properties in four soil series under different land uses and their temporal changes. Catena, 73(2), 180-188. doi:10.1016/j.catena.2007.09.009

Zimmermann, B., Elsenbeer, H., \& De Moraes, J. M. (2006). The influence of land-use changes on soil hydraulic properties: Implications for runoff generation. Forest Ecology and Management, 222(1-3), 29-38. doi:10.1016/j.foreco.2005.10.070 